Article

\title{
Synthesis of Pyrazolo-Fused 4-Azafluorenones in an Ionic Liquid. Mechanistic Insights by Joint Studies Using DFT Analysis and Mass Spectrometry
}

\author{
Efraín Polo ${ }^{1}$ (D), Valentina Arce-Parada ${ }^{2}$, Xaviera A. López-Cortés ${ }^{3}$, Jesús Sánchez-Márquez ${ }^{4}$, \\ Alejandro Morales-Bayuelo ${ }^{5}$, Oscar Forero-Doria ${ }^{6, *}$ (D) and Margarita Gutiérrez ${ }^{6, *}$ \\ 1 Doctorado en Ciencias Mención I+D de Productos Bioactivos, Instituto de Química de Recursos Naturales, \\ Laboratorio de Síntesis Orgánica, Universidad de Talca, Casilla 747, Talca 3460000, Chile; epolo@utalca.cl \\ 2 Facultad de Ciencias de la Salud, Escuela de Tecnología Médica, Universidad de Talca, Casilla 747, \\ Talca 3460000, Chile; vale_arce9@hotmail.com \\ 3 Department of Computer Science and Industries, Universidad Católica Del Maule, Maule 3340000, Chile; \\ xaviera.lopez.c@gmail.com \\ 4 Departamento de Química-Física, Facultad de Ciencias, Campus Universitario Río San Pedro, Universidad \\ de Cádiz, 11510 Puerto Real, Cádiz, Spain; jesus.sanchezmarquez@uca.es \\ 5 Ciencias de la Salud, Grupo de Investigaciones Básicas y Clínicas de la Universidad del Sinú (GIBACUS), \\ escuela de medicina, Universidad del Sinú, 130001 Cartagena, Bolivar, Colombia; \\ alejadromoraba@hotmail.com \\ 6 Instituto de Química de Recursos Naturales, Laboratorio de Síntesis Orgánica, Universidad de Talca, \\ Casilla 747, Talca 3460000, Chile \\ * Correspondence: oforero@utalca.cl (O.F.-D.); mgutierrez@utalca.cl (M.G.)
}

Received: 12 September 2019; Accepted: 27 September 2019; Published: 29 September 2019

check for updates

\begin{abstract}
A series of pyrazolo-fused 4-azafluorenones (indeno[1,2-b]pyrazolo[4,3-e]pyridines, IPP) were synthesized via the three-component reaction between arylaldehydes, 3-methyl- $1 H$-pyrazol5-amine and 1,3-indanedione in an ionic liquid as a catalyst at room temperature. The applied synthetic route has the advantages of easy work-up under mild reaction conditions presenting moderate yields and an environmentally benign procedure. A theoretical study based on conceptual-density functional theory has been done, bond reactivity indices have been calculated and an electrophilic and nucleophilic character of localized orbitals has been determined to analyze the possible electronic mechanisms.
\end{abstract}

Keywords: ionic liquid; condensation; 4-azafluorenones; ultrasound; reaction mechanism; mass spectrometry; DFT studies

\section{Introduction}

4-Azafluorenone (5H-indeno [1,2-b]pyridin-5-one) derivatives have aroused great interest in recent years due to their antimicrobial and antimalarial activities [1,2]. These compounds are inhibitors of phosphodiesterase IV [3], participate in adenosine A2a receptor binding [4], are calcium antagonists [5], and have anti-inflammatory/anti-allergic properties [6]. They are also used in the treatment of hyperlipoproteinemia and neurodegenerative diseases [4], and present anticancer activity [7]. Indenopyridine scaffold (I) is active against Candida albicans in micro molar concentrations [8], polifothine (II) is an anti-cholinergic alkaloid obtained from Polyalthia longifolia [9,10], indenoquinoline (III) shows antibacterial activity against Gram-positive and Gram-negative bacteria [11] and TAS-103 (IV) antitumor activity [12] (Figure 1). 
<smiles>Cc1ccnc2c1C(=O)c1ccccc1-2</smiles>

Onychine (I)

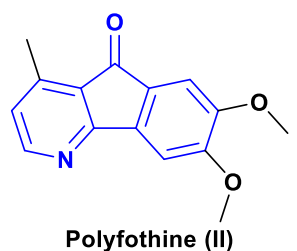<smiles>O=C1c2ccccc2-c2nc3ccccc3cc21</smiles>

(III)

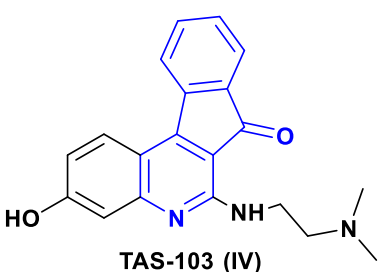

TAS-103 (IV)

Figure 1. Bioactive molecules with indenopyridine ring.

The main methodology reported for the synthesis of indeno[1,2-b]-pyrazolo[4,3-e]pyridines (IPP) includes the reaction between amino-aromatic or heteroaromatic substrates (1), aromatic or aliphatic aldehydes (2), and 1,3-indanedione (3) using conventional and unconventional methods [13] (Table 1), where 5-amino-pyrazoles are the most studied heterocyclic amines in this strategy. 3-methyl-1-phenyl-1H-pyrazole-5-amine (1) has been the most intensively studied skeleton, Nikpassand et al. (2010) reported the three-component regioselective reaction between 3-methyl-1H-pyrazol5-amine, 1,3-indanedione, and arylaldehydes in ethanol under ultrasound irradiation without achieving the aromatization of the final product [14]. Most of the reported synthetic methods for the synthesis of fused indenopyridines require high temperatures, long reaction times and the use of toxic solvents. Some of the reported methods resulted in low yields and involved cumbersome product isolation procedures. Thus, a simple, efficient, and green method to synthesize IPP is the attractive synthetic task (Table 1).

Table 1. Synthetic methods reported for the synthesis of indeno[1,2-b]-pyrazolo[4,3-e]pyridines (IPP).

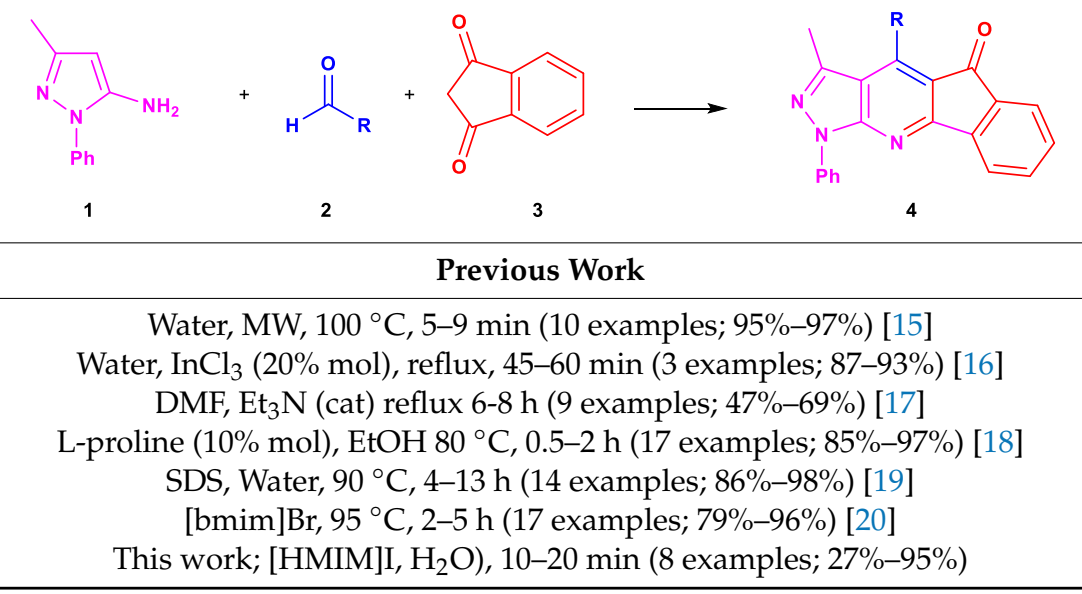

One of the most important principles of Green chemistry is the research and development of environmentally favorable chemical methodologies and technologies. In this sense, the selection of an environmentally benign solvent has gained much attention. On the basis of this fact, the selection of an environmentally benign solvent, as well as the reduction of the number of reaction steps in convergent and lineal synthetic strategies have gained much attention. Multicomponent reaction (MCR) is a convergent reaction, in which three or more starting materials react (one-pot processes) to form a product. MCRs are of great interest in diversity-oriented synthesis, especially to generate compound libraries for screening purposes. The synthetic versatility of MCRs has gained attention in modern organic synthesis as the number of their applications has significantly increased in medicinal chemistry, drug discovery programs, combinatorial chemistry, natural product synthesis, agrochemistry, synthesis of heterocyclic systems, and polymer chemistry among others [21-25].

Sonochemistry has emerged as an alternative, in the induction of organic reactions, to conventional methods. Improved reaction yields, shorter reaction times, milder conditions, less byproduct formation, and simplicity in experimental handling can be achieved. The abovementioned characteristics 
undoubtedly represent advantageous environmental factors, especially when the sonication is combined with the use of water or ionic liquids as solvents, or is applied in multicomponent reactions [26].

The use of solvents is a constant source of concern, since it gives rise to toxicity, hazard, pollution, and waste treatment issues. Solvents generally account for the major source of the wasted mass of a given process or a synthetic pathway [27]. Since many organic compounds are difficult to dissolve in water and the disposal of contaminated aqueous streams is expensive, the use of water as a solvent has certain limitations [28].

In this sense, room temperature ionic liquids (RTILs) continue to expand significantly due to their unusual physical and chemical properties, such as high thermal stability, lack of inflammability, low volatility, chemical stability, and excellent miscibility with many organic compounds. RTILs based on the 1-alkyl-3-methylimidazolium cation are a promising alternative to the conventional solvents [29]. For example, 1-alkyl-3-methylimidazolium salts have been used in many types of chemical reactions, such as Michael [30], Sakurai [31], Friedlander [32], Mannich [33], Heck [34], Suzuki cross-coupling [35] acting as solvents or catalysts.

Hydrogen bonding interaction is a cornerstone in the organocatalysis. The great ability of ionic liquids to form hydrogen bonds along with its good physicochemical properties has made these excellent organocatalysts in a various organic reaction. Being Diels-Alder [36] cycloadditions the most often applied Baylis-Hillman [37], acetylation of alcohols [38], Knoevenagel condensation [39], and aldol condensation [40].

Perhaps the potentially most powerful way in which an ionic liquid can be used in catalysis is as a combination of solvent and catalyst. The solubilities of the reaction components (starting materials, products, catalyst, and co-solvents) and any specific interaction that may take place between the solvent and solutes are of great importance in the catalysis area. The ionic liquids have been called to fulfill this dual role catalyst-solvent in catalyzing various chemical reactions. In this sense Peng and Deng (2001) described the use of RTILs based on [bmim $]^{+}$and $[\mathrm{bpy}]^{+}$as catalytic media for the cycloaddition of carbon dioxide to propylene oxide, reporting that $[\mathrm{bmim}] \mathrm{BF}_{4}$ is the best catalytic medium for the reaction [41]. On the other hand, radical polymerization of methyl methacrylate (MMA) mediated by copper (I) in [bmim] $\mathrm{PF}_{6}$ have been described by Carmichael, authors demonstrated that the ionic liquid under study is an excellent solvent for CuI-N-propyl-2-pyridylmethanimine mediated living radical polymerization of MMA [42]. In both examples, RTILs catalyst mixtures are recycled and reused.

In this work, we describe a convenient regioselective synthesis of IPP in the absence of a metal catalyst. The reactions under study present short reaction times, moderate yields, use RTILs as a catalyst-solvent and ultrasound as an energy source. All compounds were evaluated as anticholinergic and antibacterial agents. Adsorption, distribution, metabolism, and excretion (ADME) predictions revealed favorable pharmacokinetic parameters for the synthesized compounds, which warrant their suitability as potential bioactive compounds. The computational calculations explain the action mode of RTILs used in the study.

\section{Results}

Motivated by the versatility and benefits offered by multicomponent reactions and with the purpose of creating efficient, versatile, and eco-friendly methodologies, we planned a facile three-component reaction for the construction of fused indeno[1,2-b]-pyrazolo[4,3-e]pyridines (IPP) heterocycles using an aminopyrazole (1), an aldehyde derivative (2), and indanedione (3).

In an attempt to explore the reactivity, efficiency, and yields for the synthesis of a series of IPP with ionic liquid as a catalyst, we tested different conditions for the MCR where 1, nicotinaldehyde (2a) and indanedione (3) react to afford 4a using different solvents, metal catalyst and additives (see Table 2). As shown in Table 2, the expected product was obtained in good yield in water under ultrasound at room temperature (entry 4); ILs (ionic liquid) at $10 \%$ mol. Higher ILs catalyst load ( $20 \% \mathrm{~mol})$ did not improve the yield of the product to a greater extent (see Entry 6). 
Table 2. Synthesis of 4 a under different reaction conditions ${ }^{\text {a }}$.

\begin{tabular}{ccc}
\hline Entry & Conditions & Yield (\%) \\
\hline $\mathbf{1}$ & EtOH, Sonication, 20 min & 60 \\
$\mathbf{2}$ & $\mathrm{H}_{2} \mathrm{O}$, Sonication, 20 min & - \\
$\mathbf{3}$ & $\mathrm{AcOH}$, Sonication, 1,5 h & 65 \\
$\mathbf{4}$ & {$[\mathrm{HMIM}] \mathrm{I}(10 \%)$, Sonication, 10 min } & 95 \\
$\mathbf{5}$ & {$[\mathrm{HMIM}] \mathrm{I}(15 \%)$, Sonication, 10 min } & 92 \\
$\mathbf{6}$ & {$[\mathrm{HMIM}$ ] (20\%), Sonication, 10 min } & 92 \\
$\mathbf{7}$ & $\mathrm{InCl}_{3},(10 \%)$, Water, Sonication 30min & 54 \\
$\mathbf{8}$ & $\mathrm{InCl}_{3},(20 \%)$, Water, Sonication 30min & 68 \\
\hline
\end{tabular}

a Reaction conditions: $2 \mathrm{~mL}$ ionic liquid or $2 \mathrm{~mL}$ organic solvent (entry 1, 2, and 3), nicotinaldehyde (2; $0.107 \mathrm{~g}$, $1.0 \mathrm{mmol})$, aminopyrazole $(1 ; 0.173 \mathrm{~g}, 1.0 \mathrm{mmol})$, and indanedione $(3 ; 0.146 \mathrm{~g}, 1.0 \mathrm{mmol})$.

To optimize this methodology, different IPP (4a-k), were prepared using several aldehydes $(3 a-j)$. Table 3 shows the structure, yield, and melting point of the prepared compounds. Moreover, synthesized compounds were evaluated as cholinesterase inhibitors (for $\mathrm{IC}_{50}$ values see Table 3 ).

In order to study this protocol in relation to the 1,3-dicarbonyl component, we carried out the reaction with the following compounds, 1,3-dicarbonyl: 2,4-pentanedione, ethyl acetoacetate, and active methylene 1 -indanone generating the compounds $4 \mathrm{i}, 4 \mathrm{j}$, and $4 \mathrm{k}$ respectively. As we can see, all the active methylenes (3) were efficiently annulated with aldehydes $(2 a-k)$ generating the corresponding Knoevenagel adduct intermediate (5), evidence of the above were the compounds 5a-c, which failed to make the Michael addition

As a general trend, this reaction is tolerant to a large variety of aldehydes (with electron-withdrawing and electron-releasing substituents). Diverse adducts could be prepared in good yields (up to 95\%), demonstrating the versatility of this one-pot process. This variety of results seems very attractive for the establishment of structure-activity relationships for biological evaluation.

In many cases, ionic liquids can be easily recycled, based on this background $[43,44]$, we decided to carry out the recycling experiments in which the IL was reused. Different cycles were realized in the consecutive obtainment of $4 \mathrm{a}$. A total of three cycles were realized, between cycle and cycle the product of the reaction was obtained by centrifugation and filtration of the resulting mixture. [HMIM]I-water solution was recovered and reused and its reaction yield was calculated. In the first cycle, 4a was obtained with $95 \%$ yield in $10 \mathrm{~min}$ after the reaction started. Consecutively, the resulting IL was reused for cycles 2 and 3 and we obtained a $72 \%$ and $41 \%$ yield respectively (Table 4 ).

A reasonable mechanism for the synthesis of products $4 \mathrm{a}-\mathrm{k}$ is outlined in Scheme 1. It expects to proceed via Knoevenagel condensation of 2 and 3 giving an intermediate 5. It may be proposed that the [HMIM]I catalyst facilitates the formation of the intermediate 5 acting as Lewis acid, and removing the necessity of use of an additional acid catalyst. The Lewis acidity is conferred by the - $\mathrm{CH}$ proton between nitrogen atoms of imidazole core, capable of bonding with the carbonyl oxygen of the diketone 3 , which reacted with aldehyde 2 to afford the intermediate 5, the Michael addition of the latter with 1 open-chain intermediate [6], which is subsequently cyclized, dehydrated, and dehydrogenated to afford the aromatized product $4[45,46]$. In an attempt to confirm the proposed reaction mechanism, a screening of the three-component reaction was performed by time-of-flight mass spectrometry (TOFMS) in the positive mode and an off-line manner. Figures 2 and 3 show the full-scan positive ion ESI (Electrospray ionization) mass spectrum progress of the reaction employing the optimized reaction conditions "entry 4" (Table 2). Thus at the beginning of the reaction the ions at $\mathrm{m} / \mathrm{z} 146$ and 167 corresponding to the species $[3]^{+}$and $[\mathrm{HMIM}]^{+}$were observed, after two minutes of the reaction the ion at $\mathrm{m} / \mathrm{z} 441\left[3-[\mathrm{HMIM}]^{-}\right]^{+}$resulted at the adduct formation 3 was observed (Scheme 1). The formation of adduct 3 confirms the ability of [HMIM] $\mathrm{I}^{-}$as a Lewis acid catalyst. Additionally the ion at $\mathrm{m} / \mathrm{z}$ $108[2 \mathrm{a}+\mathrm{H}]^{+}$was observed in the ESI-MS spectrum (Figure 3a). After five minutes of the reaction we observed the ion at $\mathrm{m} / \mathrm{z} 420\left[5-[\mathrm{HMIM}]+\mathrm{H}_{2} \mathrm{O}\right]^{+}$corresponding to aldolic condensation between nicotinaldehyde $2 \mathrm{a}$ and the diketone activated 3 containing to [HMIM] $\mathrm{I}^{-}$through intermolecular 
hydrogen bonding (Figure 3b), also the final product of Knoevenagel condensation (ion at m/z 237 [5 + $2 \mathrm{H}]^{+}$) was observed. At this point the Michael addition of 1 to 5 was carried out and subsequently cycled, dehydrated, and dehydrogenated to afford the aromatized product 4 .

Table 3. Synthesis of indeno[1,2-b]-pyrazolo[4,3-e]pyridines (IPP; 4a-k).

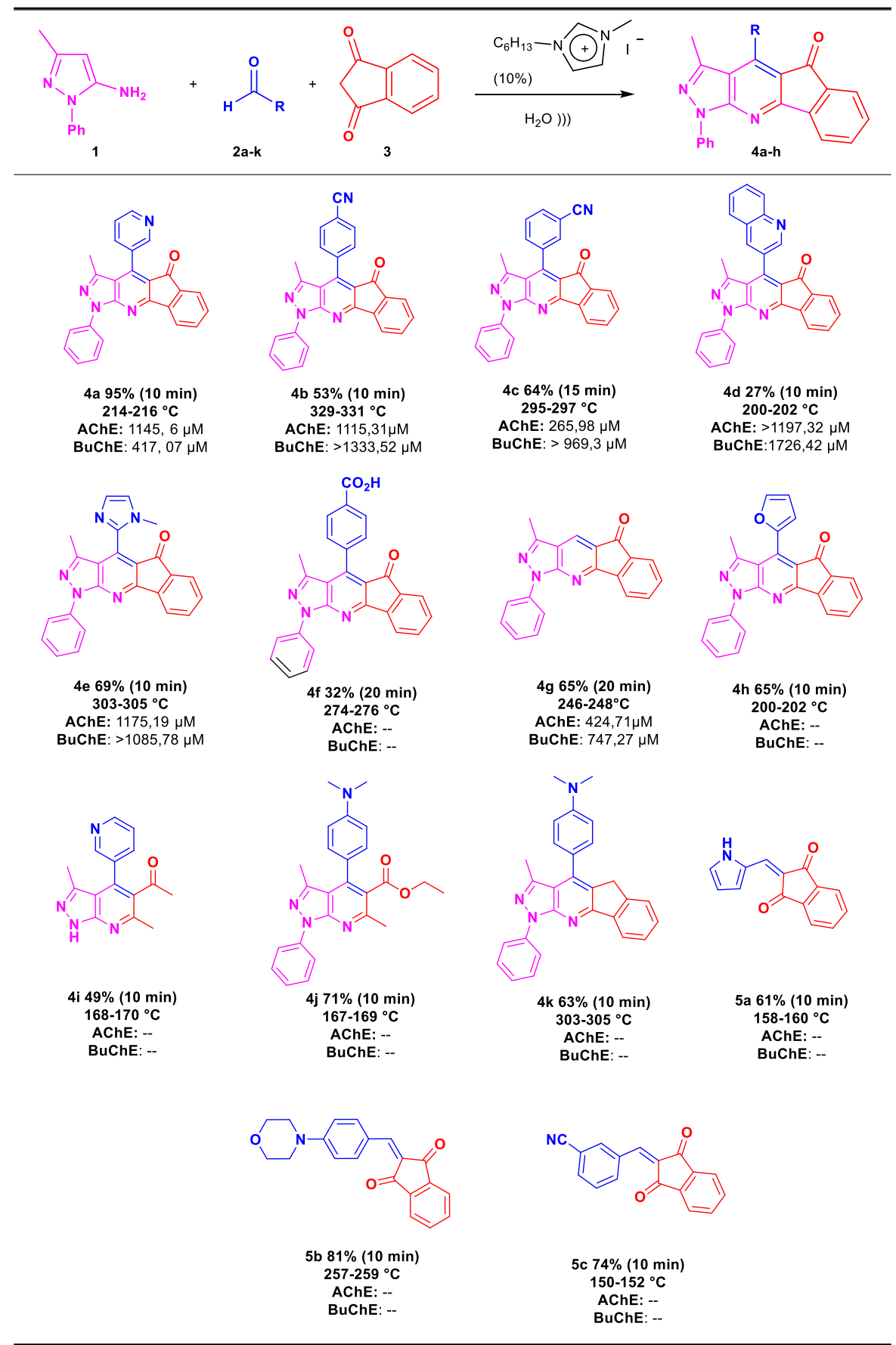

Table 4. Recyclability of [HMIM]I in the construction of indeno[1,2-b]-pyrazolo[4,3-e]pyridines 4a.

\begin{tabular}{cccc}
\hline Cycle & Time (min) & Product & Conv (\%) \\
\hline 1 & 10 & $4 \mathrm{a}$ & 95 \\
2 & 10 & $4 \mathrm{a}$ & 72 \\
3 & 10 & $4 \mathrm{a}$ & 41 \\
\hline
\end{tabular}



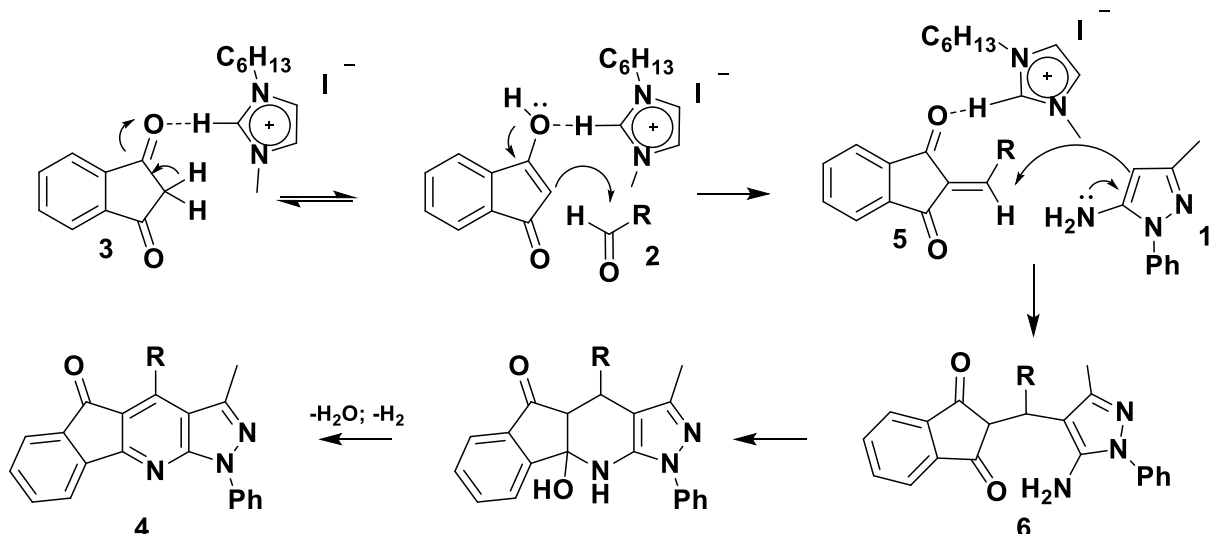

Scheme 1. The plausible reaction mechanism for the formation of IPP 4.
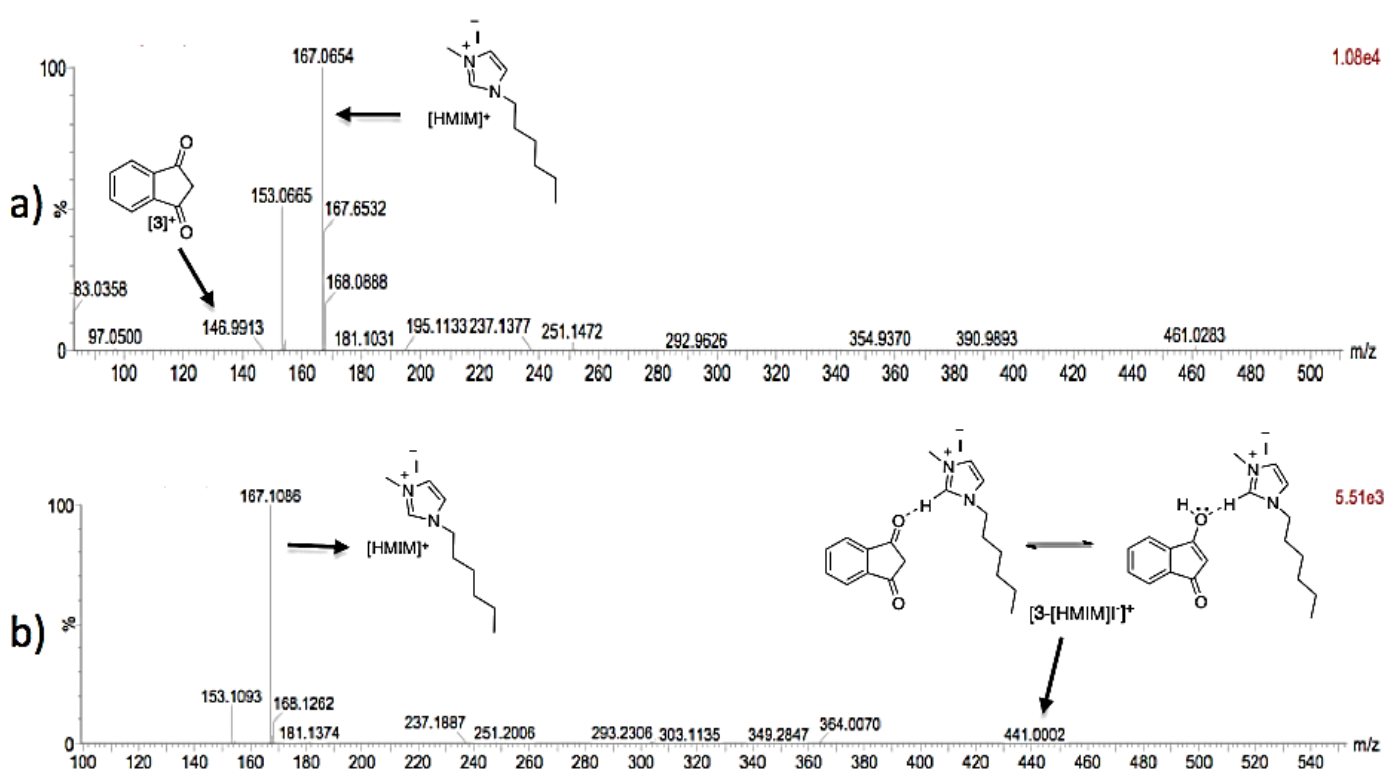

Figure 2. Full scan positive ion ESI (Electrospray ionization) mass spectrum progress of the threecomponent reaction: (a) $\mathrm{t}=0$ and $(\mathbf{b}) \mathrm{t}=2 \mathrm{~min}$.

a)
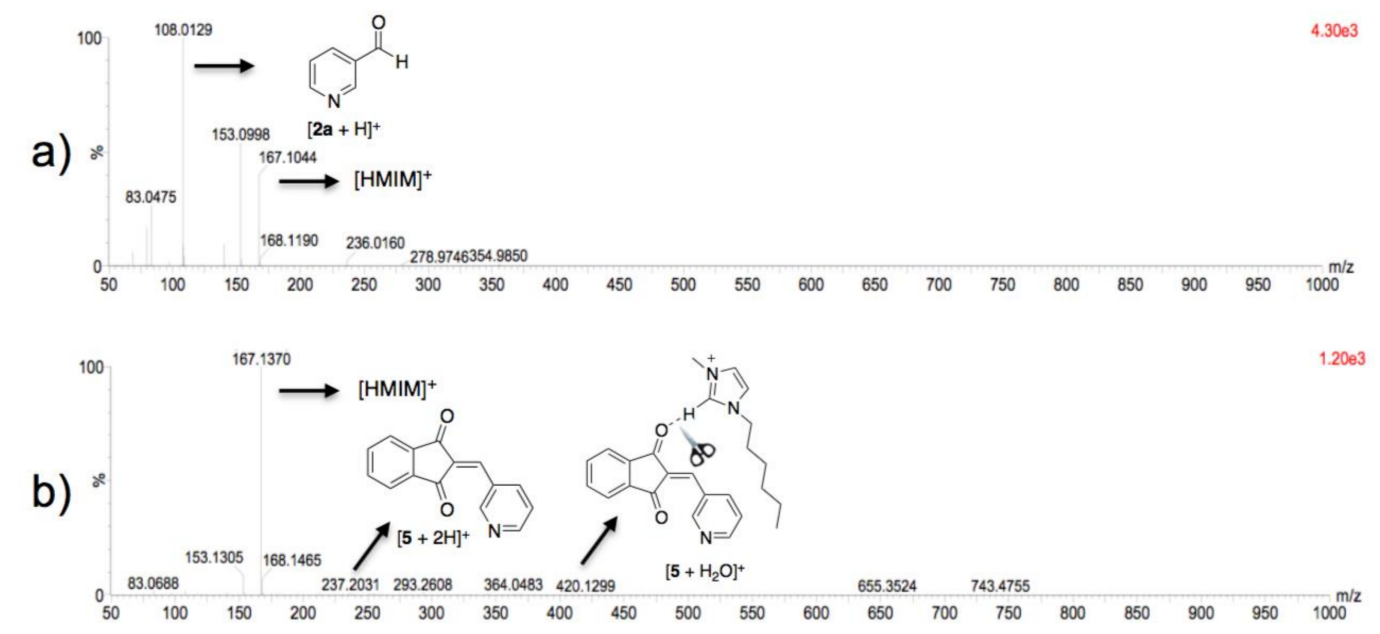

Figure 3. Full scan positive ion ESI mass spectrum progress of the three-component reaction: (a) $\mathrm{t}=3 \mathrm{~min}$ and (b) $\mathrm{t}=5 \mathrm{~min}$. 


\section{Theoretical Analysis}

The influence of the catalyst in the first stages of the reaction was analyzed, which was where a greater influence of the catalyst was expected. In each of the three systems of Scheme 2 the reactivity with and without the catalyst was compared. The theoretical reactivity has been studied using bond reactivity indices $\Delta f_{i}^{(N B O)}[47,48]$ based on a dual descriptor [49] and projected on the natural bond orbitals (NBOs) obtained for each system [50,51].
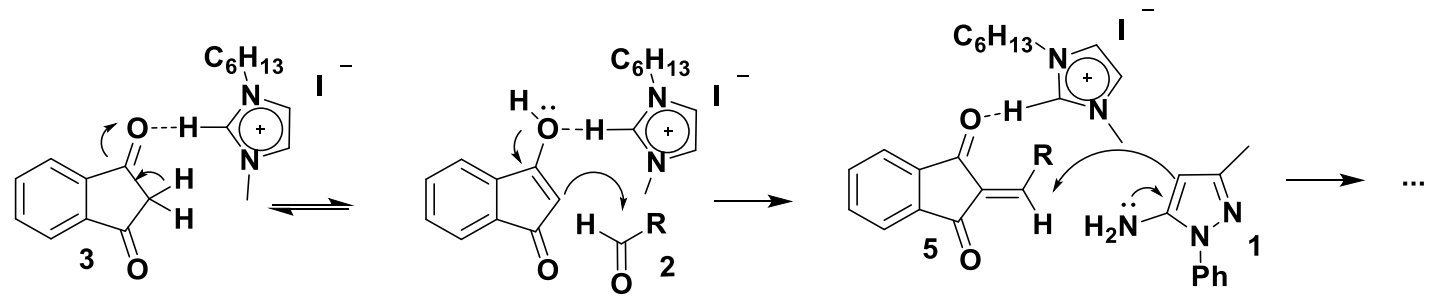

Scheme 2. Reasonable reaction mechanism for the first stages of the reaction.

\subsection{Effect of the Field Generated by the Catalyst}

The catalyst used in the experimental study [HMIM]I has been taken into account by the field created by a partial charge (of +0.209 electrons) without a base that has been obtained using the Hirshfeld population analysis $[52,53]$ and also it has been taken into account when the molecular geometry was optimized. In this case, the use of partial charges without a base has the important advantage of not introducing basis set superposition error (BSSE) in the comparisons. It was expected that the interaction of the reactants with the catalyst was electrostatic, this justifies satisfactorily that the catalyst was replaced by the main charge that influences the reactants.

\subsection{Theoretical Analysis of the First System}

Scheme 3 shows the mechanism proposed for the first stage of the reaction. Figure 4 shows a graph with the values of the bond reactivity index corresponding to the NBOs with the greatest influence on the reactivity of Scheme 3 (for simplicity, core orbitals and high-energy Rydberg orbitals were excluded). In this case the calculations were made without including the catalyst. As it can be seen, the NBOs with the most nucleophilic character are the lone-pairs (LPs) NBOs 36 and 37 (O15 and $\mathrm{O} 16$ atoms respectively). On the other hand, the most electrophilic orbitals were NBOs 39 and 40 $\pi$-antibonding orbitals (bonds C7-O16 and C9-15 respectively). It is worth noting that the symmetry of the reactivity index values was coherent with the symmetry of the molecule and this did not happens (see below) when we considered the field of the catalyst in the calculations.

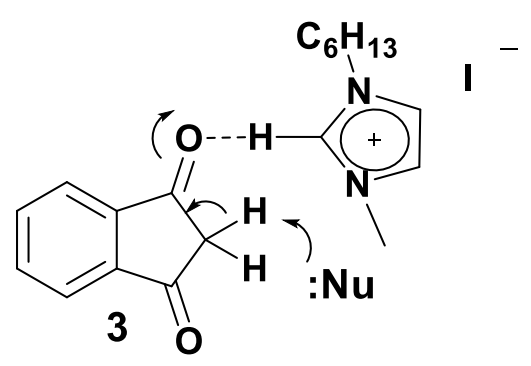

Scheme 3. Reasonable reaction mechanism for the first stage of the reaction. 

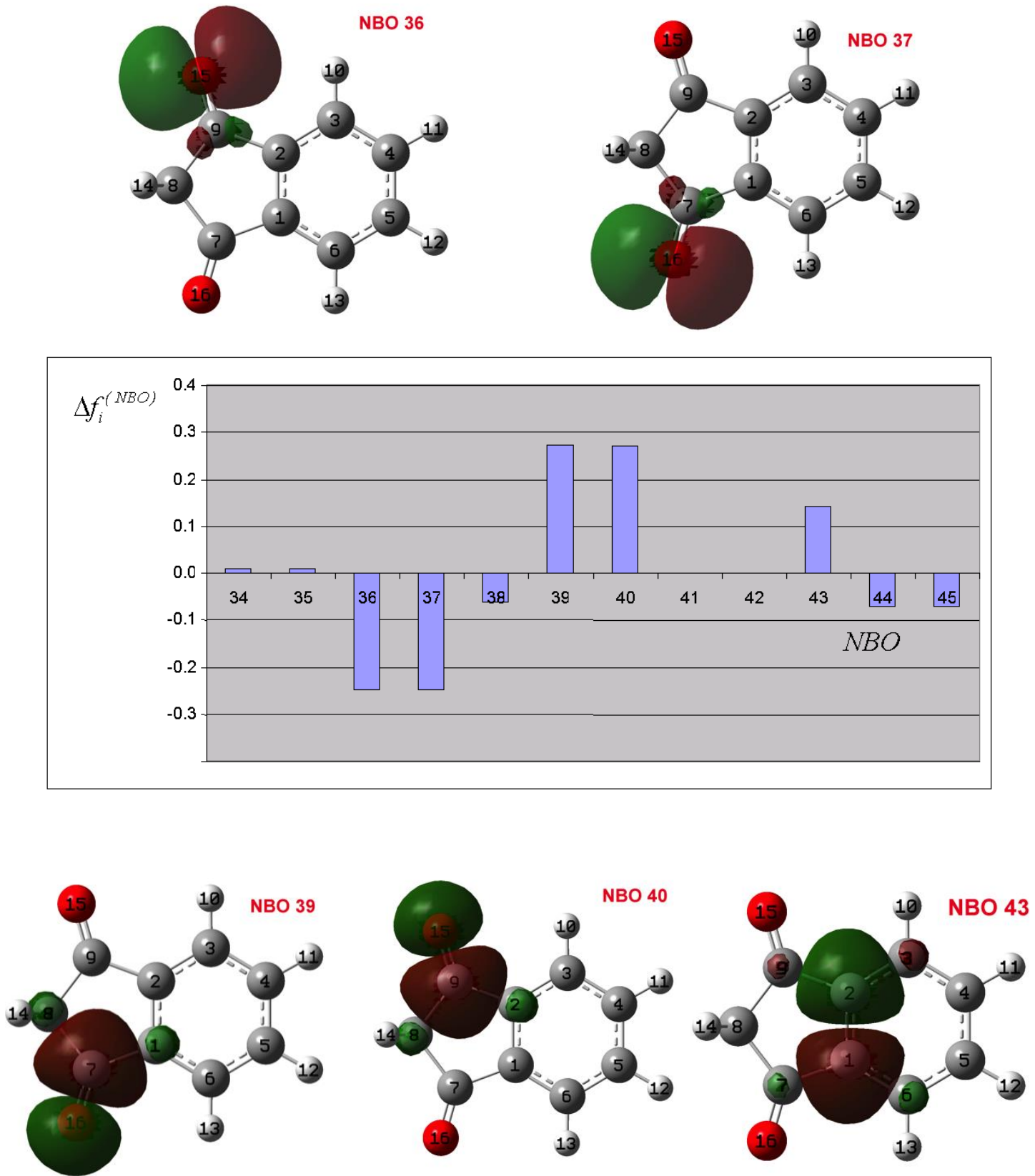

Figure 4. Bond reactivity index $\Delta f_{i}^{(N B O)}$ corresponding to the natural bond orbitals (NBOs) with the greatest influence on the reactivity of Scheme 3. In this case the calculations were made without including the catalyst.

Figure 5 shows the values of the bond reactivity index $\Delta f_{i}^{(N B O)}$ of the most relevant NBOs for the reactivity of Scheme 3, but this case the catalyst was included in the calculations. It can be seen that the NBOs with the highest nucleophilic character were the LPs NBO 34 and 36 (O15 and O16 respectively) but now the values were different, the value of one of them had increased while the other one had decreased due to the effect of the catalyst. Something equivalent happens with the orbitals, with a higher electrophilic character, NBOs 39 and 41 ( $\pi$-antibonding orbitals of double bonds C7-O16 and C9-15). The increase of the electrophile character of NBO 41 helped the electronic movements of Scheme 3, since this orbital attracted the displaced charge due to the loss of hydrogen H14 and stabilized the displaced charge of the bond C7-O16 ( $\pi$-bonding), on the other hand the increase in the 
nucleophilic character of LP NBO 36 helped the uptake of a solvent proton and the formation of the alcohol group (see Scheme 2).
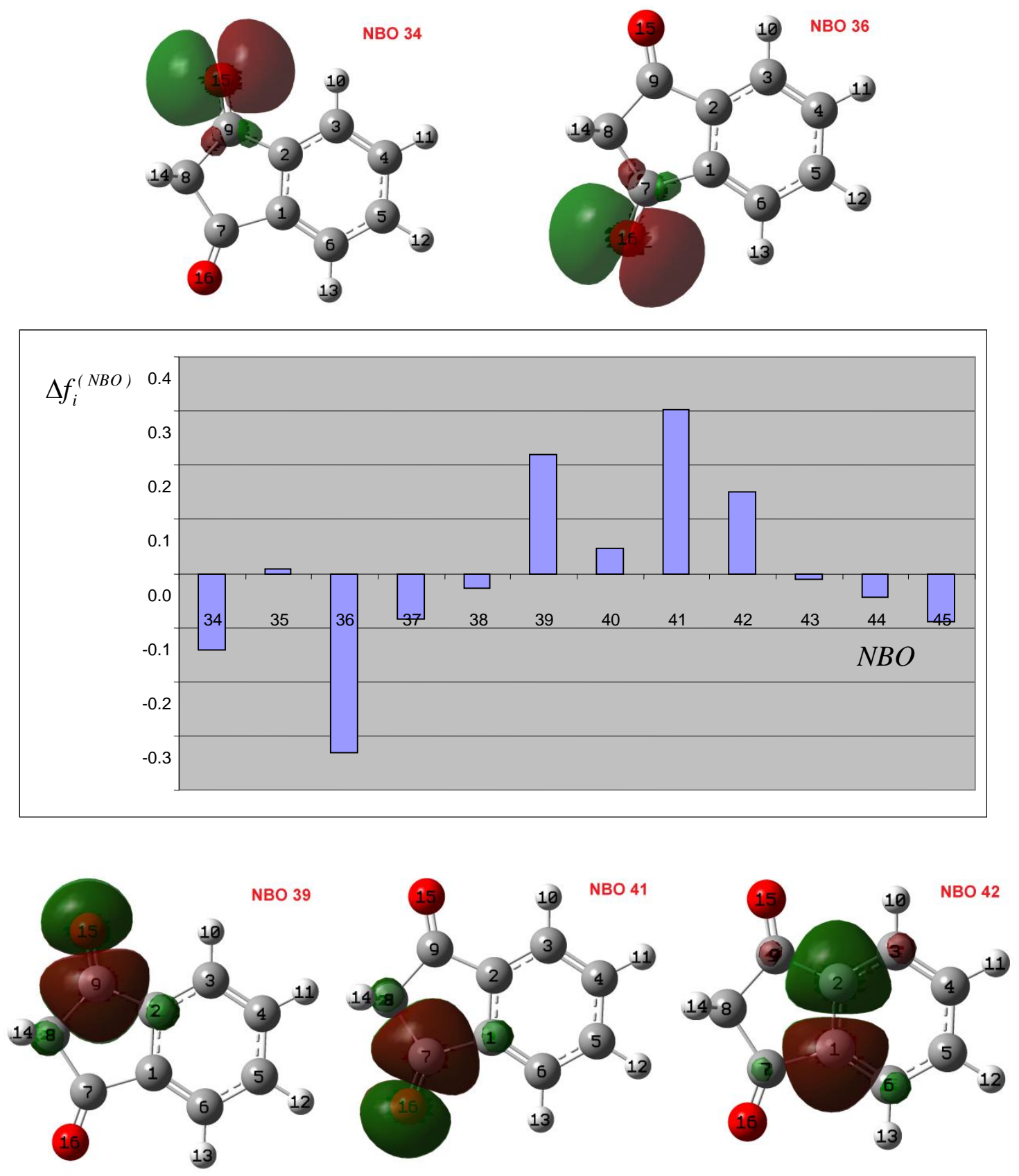

Figure 5. Bond reactivity index $\Delta f_{i}^{(N B O)}$ corresponding to the NBOs with the greatest influence on the reactivity of Scheme 3. In this case the calculations were made including the catalyst.

\subsection{Theoretical Analysis of the Second System}

Scheme 4 shows the mechanism proposed for the second stage. In Figure 6 you can see a graph with the values of the bond reactivity index $\Delta f_{i}^{(N B O)}$ for the most important NBOs of the reactivity of Scheme 4. In this case the calculations were made without including the catalyst. As can be seen, the highest nucleophilic localized-orbital was the $\pi$-bonding NBO 34 (bond C8-C9) and the highest electrophilic one was the $\pi$-antibonding NBO 39 (bond C8-C9). In this case, Figure 7 shows that the effect of the catalyst had almost no influence on the bond reactivity indices. In any case, the values obtained for the NBOs were consistent with the reactivity shown in Scheme 4, the high nucleophilic 
character of the NBO 34 justified the attack to the carbonyl group by the electrons of the C8-C9 double bond and the electrophilic character of the NBO 39 helped the displacement of the electron pair from $\mathrm{O} 15$ to $\mathrm{C} 9$ and the formation of the double bond C9-O15.

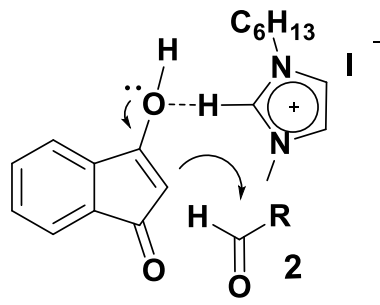

Scheme 4. Reasonable reaction mechanism for the second stage of the reaction.
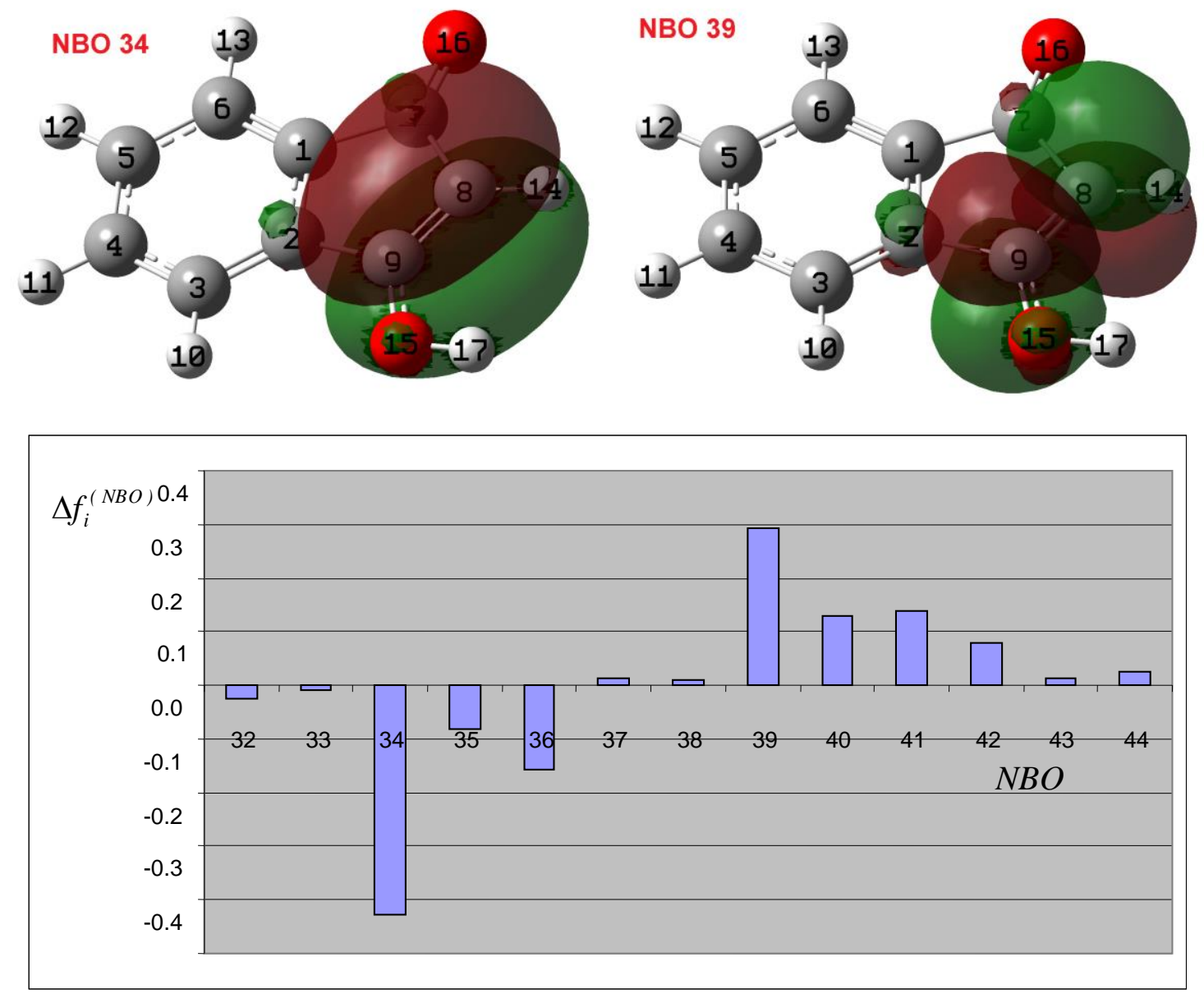

Figure 6. Bond reactivity index $\Delta f_{i}^{(N B O)}$ corresponding to the NBOs with the greatest influence on the reactivity of Scheme 4 . In this case the calculations were made without including the catalyst. 

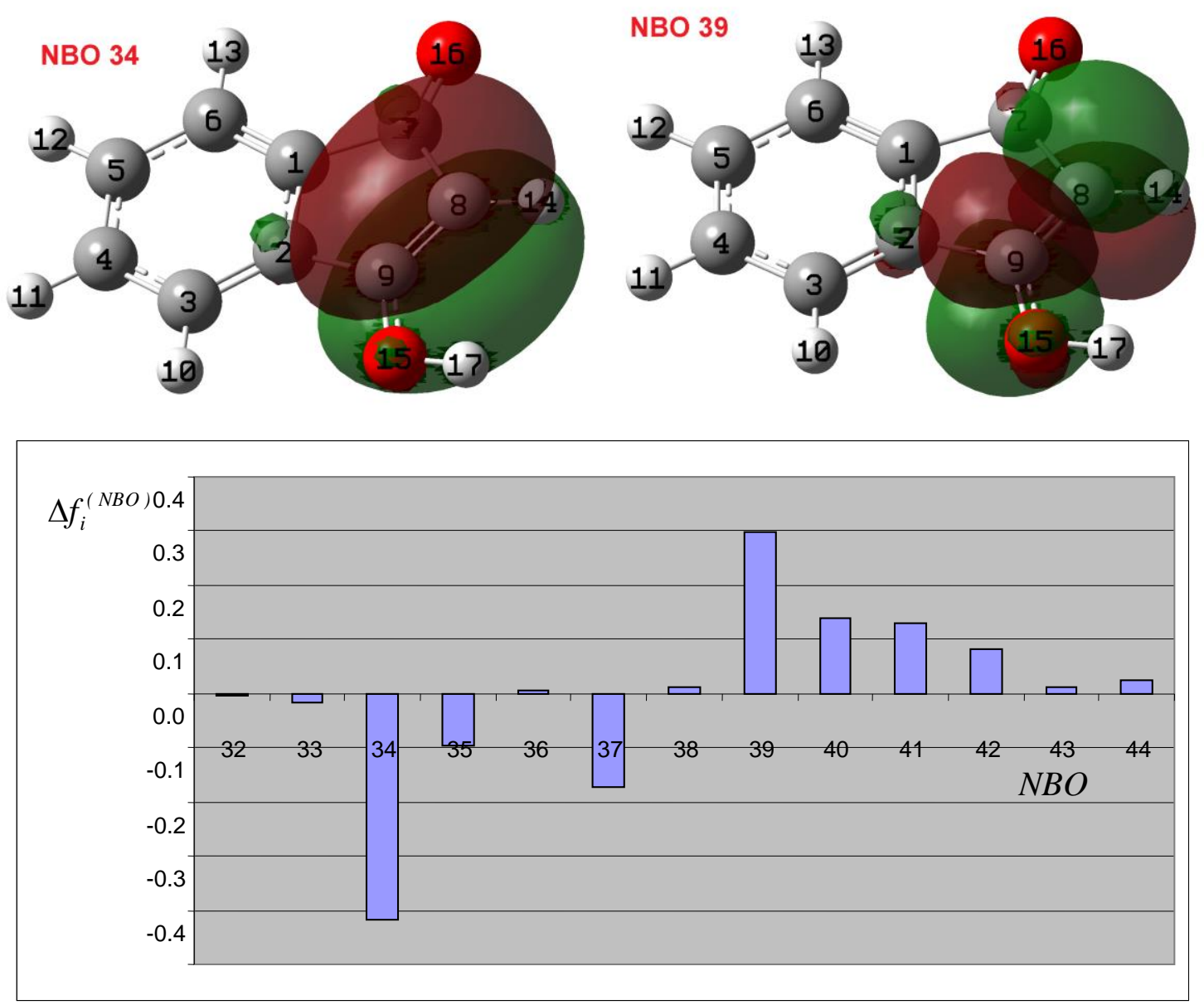

Figure 7. Bond reactivity index $\Delta f_{i}^{(N B O)}$ corresponding to the NBOs with the greatest influence on the reactivity of Scheme 4 . In this case the calculations were made including the catalyst.

\subsection{Theoretical Analysis of the Third System}

Scheme 5 shows the proposed mechanism for the third stage and Figure 8 a graph with the values of the bond reactivity index $\Delta f_{i}^{(N B O)}$ for the most reactive NBOs in this stage. In this case the calculations were made without including the catalyst. The NBOs with greater nucleophilic character were the NBOs 39 and 40 (LPs of O13 and O14), on the other hand the orbitals of greater electrophilic character were the $\pi$-antibonding NBOs 42 and 43 (bonds C8-O13 and C7-14), the $\pi$-antibonding NBO 47 also had a high electrophilic character but somewhat less. In Figure 9 we can see that the effect of the catalyst was similar to the first stage, the NBOs with the most electrophilic character were still the $\pi$-antibonding NBOs 42 and 43 (bonds $\mathrm{C} 8-\mathrm{O} 13$ and C7-14) but the values were no longer equal, the value of the NBO 42 had increased while the NBO 43 had decreased due to the effect of the catalyst, the increase of the NBO 42 helped the Scheme 5 mechanism since it facilitated the electronic movement of the electrons of the double bond $\mathrm{C} 15-\mathrm{C} 16$ towards the $\mathrm{C} 8-\mathrm{C} 15$ bond and the electrons of the $\mathrm{C} 8-\mathrm{O} 13$ double bond towards the $\mathrm{O} 13$ atom. On the other hand, the $\pi$-antibonding NBO 47 that had a high electrophilic character and the greater influence in Scheme 5 had not been affected by the catalyst. 


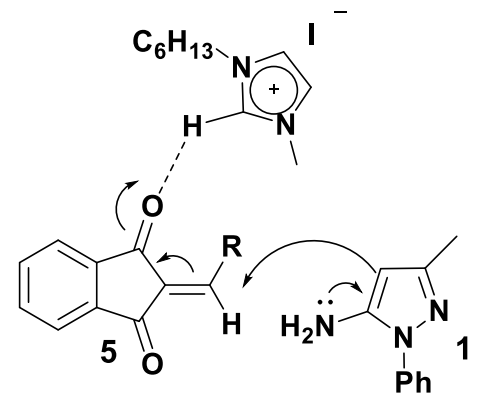

Scheme 5. Reasonable reaction mechanism for the third stage of the reaction.
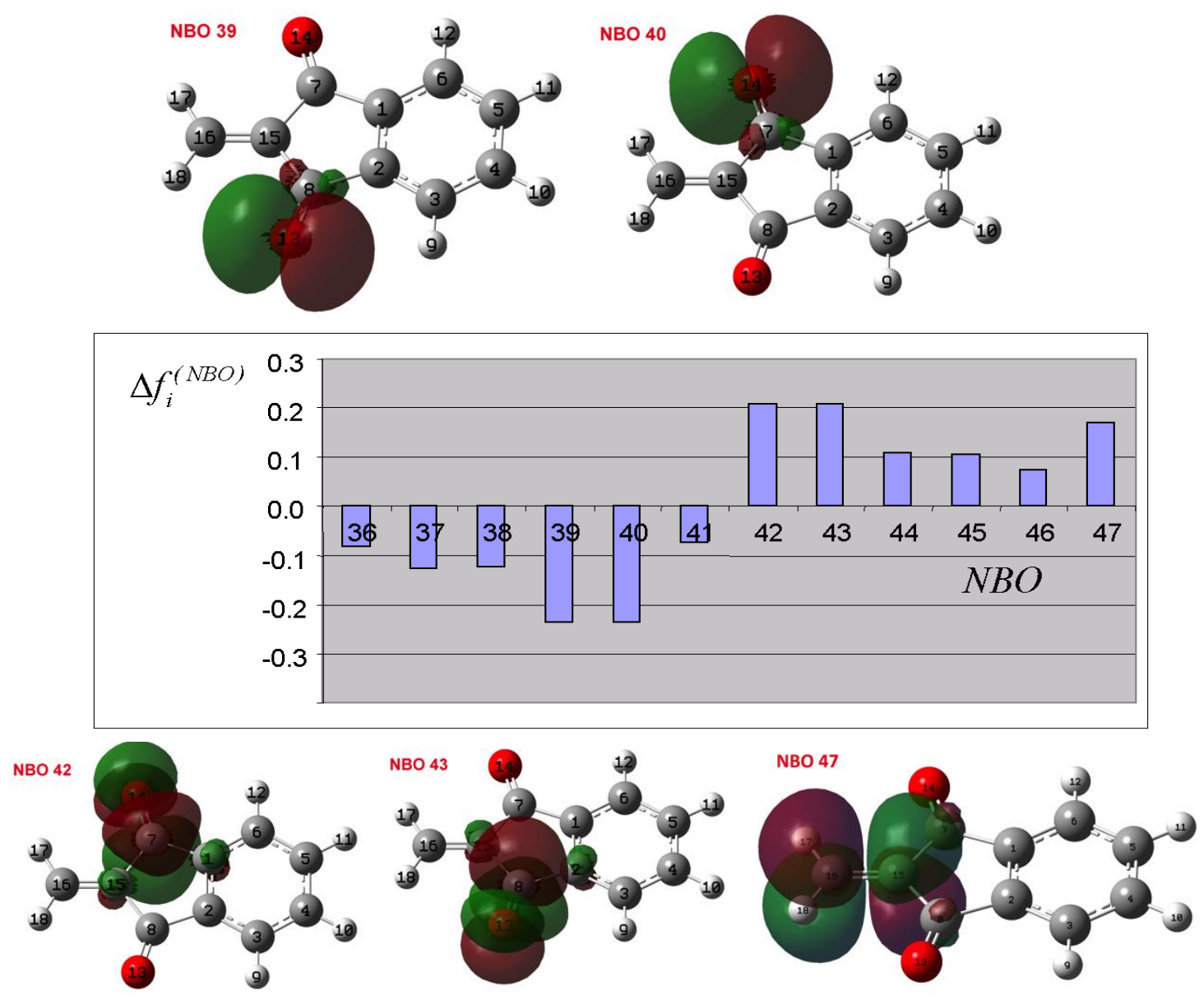

Figure 8. Bond reactivity index $\Delta f_{i}^{(N B O)}$ corresponding to the NBOs with the greatest influence on the reactivity of Scheme 5. In this case the calculations were made without including the catalyst. 

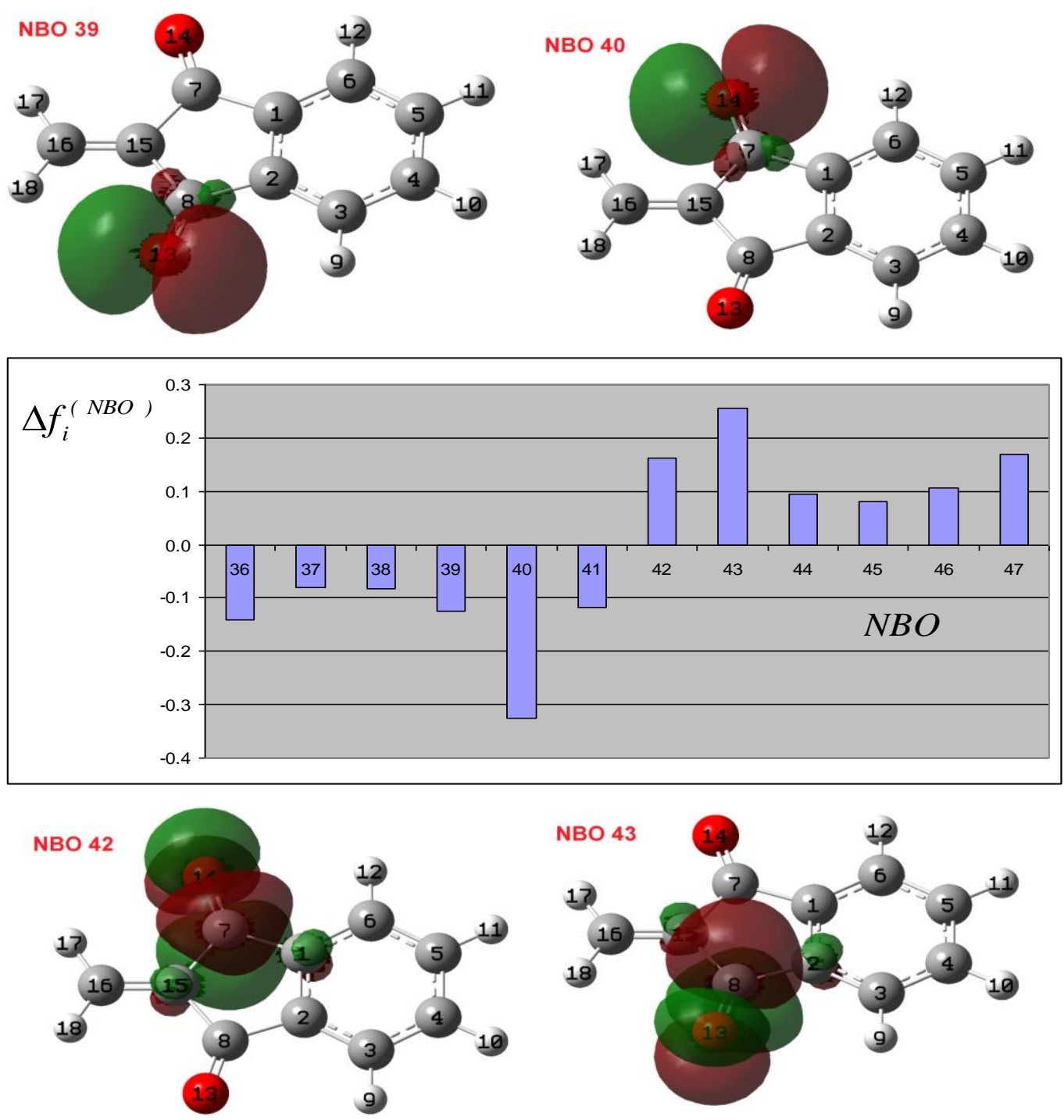

Figure 9. Bond reactivity index $\Delta f_{i}^{(N B O)}$ corresponding to the NBOs with the greatest influence on the reactivity of Scheme 5 . In this case the calculations were made including the catalyst.

\section{Biological Activities}

All compounds were tested for the acetylcholinesterase (AChE) and butyrilcholinesterase (BuChE) inhibition and the respective inhibitory activities were studied using the method described by Ellman [54] in order to determine the rate of hydrolysis in the presence of the inhibitor. The cholinesterase activity was compared with galanthamine as a reference compound.

Among 13 compounds under study, only $4 \mathrm{c}$ and $4 \mathrm{~g}$ presented moderate activity against $\mathrm{AChE}$, with $\mathrm{IC}_{50}$ values of 265 and $424 \mu \mathrm{M}$ respectively. However, these $\mathrm{IC}_{50}$ values were not comparable with galanthamine $(0.54 \mu \mathrm{M})$, which was used as a standard inhibitor. The other 11 compounds showed $\mathrm{IC}_{50}$ values higher than $500 \mu \mathrm{g} / \mathrm{mL}$ and therefore, were not interesting as feasible $\mathrm{AChE} / \mathrm{BuChE}$ inhibitors.

To elucidate the binding mechanism of $4 \mathrm{c}\left(\mathrm{IC}_{50}=265 \mu \mathrm{M}\right)$ with $\mathrm{AChE}$ (X-ray crystal structure PDB code: 4eys, protein data bank) we performed its docking study by utilizing the Glide program [55]. The Glide program is contained in Maestro 11.0 software and Glide docking uses a series of hierarchical filters to find the best possible ligand binding locations in a previously built receptor grid space. The filters include a systematic search approach, which samples the positional, conformational, and orientational space of the ligand before evaluating the energy interactions between the ligand and the protein [55]. It is well known that two distinct binding sites exist in the active pocket of AChE 
peripheral binding site (PAS) and catalytic active site (CAS), located at the entrance and the bottom of the active-site gorge, respectively. These sites are characterized by two tryptophan residues, $\operatorname{Trp}$ 84 at the active site and Trp 279 at the peripheral of the gorge (PAS). The simultaneous binding to both the CAS and PAS has been suggested to be important in designing powerful and selective AChE inhibitors [56]. The $\pi-\pi$ stacking interactions between Trp286, pyridine aromatic rings, indene (in the PAS), and Tyr 72 (at the entrance to the gorge leading) for compound $4 \mathrm{c}$ are presented in Figure 10. Due to the lack of interaction with CAS, this binding mode caused its lower inhibitory activities against AChE.
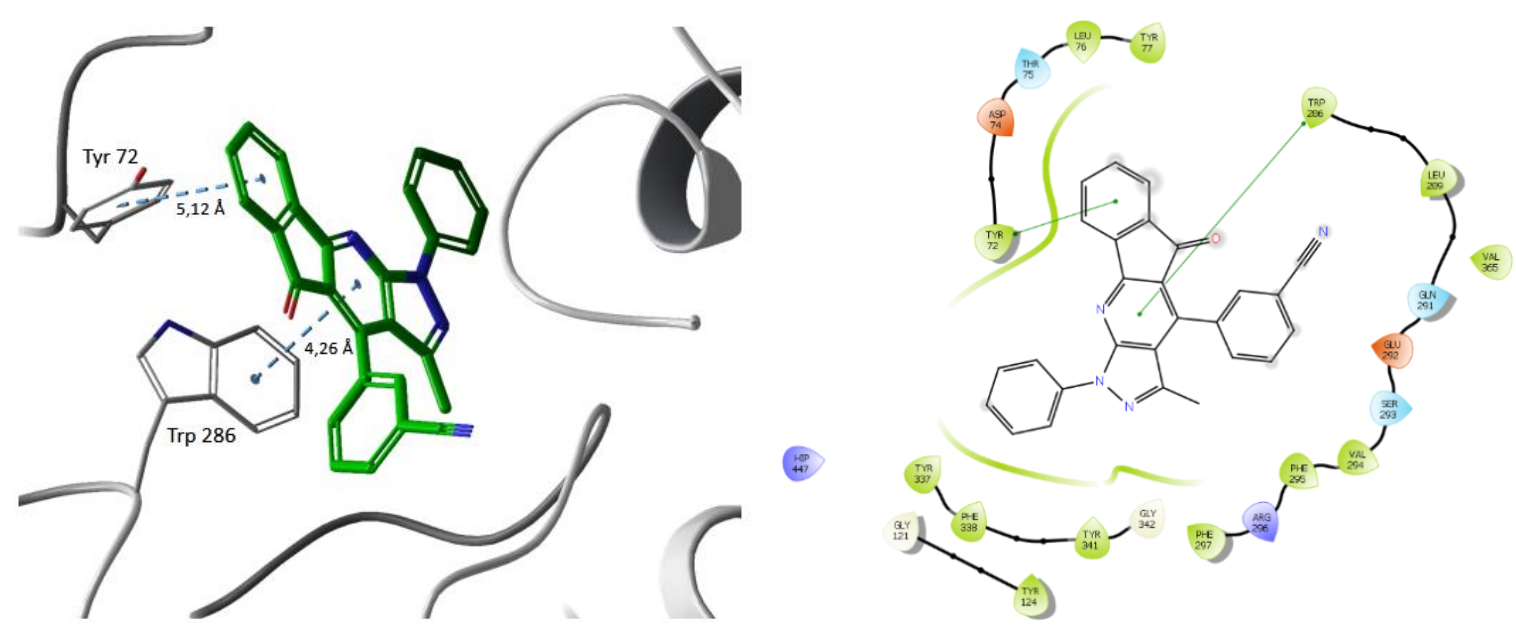

Figure 10. Molecular docking for compound $4 \mathrm{c}$ within the AChE binding site, the protein residue that form the main interactions with the inhibitor is highlighted.

Antimicrobial activities of Indeno-Pyridines $4 \mathrm{a}-\mathrm{h}$ were evaluated using the microdilution method [57]. The microorganisms used in these studies were Escherichia coli and Klebsiella pneumoniae, human clinical isolated and Gram-positive bacteria, Enterococcus faecalis. The MIC values of all compounds under study were between 400 and $1600 \mu \mathrm{g} / \mathrm{mL}$, considerably exceeding the existing values for standard antibiotics. The absorption, distribution, metabolism, and excretions (ADME) properties of the molecules were obtained by the Molinspiration program; predicting some physical and pharmaceutical properties (Table 5). It has been confirmed from previous research data that the standard values for molecular weight (MW) and the polar surface area (PSA) are in the range from 160 to $480 \mathrm{~g} / \mathrm{mol}$ and $<89 \AA 2$ respectively. The predicted MW and PSA values for compounds 4a-h were comparable with standard values (Table 5). Lipinski's rule of five (RO5) values also confirmed the therapeutic potential of the ligands. Hydrogen-bonding capacity was identified as an important parameter for describing drug permeability. Research data revealed that poor permeation was more likely when the HBA (hydrogen bond acceptors) and HBD (hydrogen bond donors) exceed 10 (unidades) and 5 respectively. The chemo-informatic analysis justified that the designed compounds possessed HBA and HBD values less than 10 and 5, respectively.

Table 5. Calculated physicochemical descriptors for compounds $4 \mathrm{a}-\mathrm{k}^{\mathrm{a}}$.

\begin{tabular}{ccccccccccccc}
\hline Property & Optimal Range & $\mathbf{4 a}$ & $\mathbf{4 b}$ & $\mathbf{4 c}$ & $\mathbf{4 d}$ & $\mathbf{4 e}$ & $\mathbf{4 f}$ & $\mathbf{4 g}$ & $\mathbf{4 h}$ & $\mathbf{4 i}$ & $\mathbf{4 j}$ & $\mathbf{4 k}$ \\
\hline MW & $<500$ & 388 & 412 & 412 & 438 & 391 & 431 & 311 & 377 & 416 & 414 & 266 \\
Log P & $<5$ & 4.88 & 5.37 & 5.35 & 5.77 & 4.00 & 5.53 & 3.89 & 4.76 & 6.08 & 4.69 & 1.87 \\
H Bond donors & $<5$ & 0 & 0 & 0 & 0 & 0 & 1 & 0 & 0 & 0 & 0 & 1 \\
H Bon Acceptors & $<10$ & 5 & 5 & 5 & 5 & 6 & 6 & 4 & 5 & 4 & 6 & 5 \\
Rotable Bonds & $<5$ & 2 & 2 & 2 & 2 & 2 & 3 & 1 & 2 & 3 & 6 & 2 \\
TPSA & $<89$ & 60.68 & 71.58 & 71.58 & 60.68 & 65.61 & 85.09 & 47.79 & 60.93 & 33.96 & 60.96 & 71.54 \\
\hline
\end{tabular}

${ }^{a}$ Values were calculated using Molinspiration Cheminformatics Software (2015), (http://www.molinspiration.com). 
The analysis of the theoretical results shows few violations of Lipinski's rule because the major calculated descriptors and properties were within range (molecular weight $\left(\mathrm{g}^{*} \mathrm{~mol}^{-1}\right)=254-335$; $\mathrm{Log}$ $\mathrm{P}=2.623-3.381, \mathrm{HB}$ acceptors $=4-4.475$, and HB donors $=0-0.5$ ). Additionally, PSA is a parameter important in the membrane penetration and the absorption and distribution of drugs respectably were analyzed and the results were in the acceptable range.

\section{Materials and Methods}

\subsection{Chemicals and Apparatus}

The ultrasonic irradiation was performed by using a Branson ultrasonic cleaner bath, model 1510, $115 \mathrm{v}, 1.9 \mathrm{~L}$ with a mechanical timer ( $60 \mathrm{~min}$ with continuous hold) and heater switch, $47 \mathrm{kHz}$. The ionic liquid was performed by using a Discover microwave apparatus (CEM Corporation, Matthews, NC, USA). ${ }^{1} \mathrm{H}$ and ${ }^{13} \mathrm{C}$ NMR spectra (400 MHz for proton and $100 \mathrm{MHz}$ for carbon) were recorded on an AM-400 spectrometer (Bruker, Rheinstetten, Germany), using $\mathrm{CDCl}_{3}, \mathrm{DMSO}-\mathrm{d}_{6}$, and $\mathrm{CD}_{3} \mathrm{OD}$ as solvents. Tetramethylsilane (TMS) was used as an internal standard. IR spectra (KBr pellets, $500-4000 \mathrm{~cm}^{-1}$ ) were recorded on a NEXUS 670 FT-IR spectrophotometer (Thermo Nicolet, Madison, WI, USA). High-resolution mass spectrometry ESI-MS and ESI-MS/MS analyses were conducted in a high-resolution hybrid quadrupole (Q) and orthogonal time-of-flight (TOF) mass spectrometer (Waters/Micromass Q-TOF micro, Manchester, UK) with a constant nebulizer temperature of $100{ }^{\circ} \mathrm{C}$. Melting points (uncorrected) were measured on an Electrothermal IA9100 melting point apparatus (Stone, Staffs, UK). Reaction progress was monitored by means of thin-layer chromatography using silica gel 60 (Merck, Darmstadt, Germany). All reagents were purchased from either Merck or Sigma Aldrich (St. Louis, MO, USA) and used without further purification.

\subsection{Procedure for the Synthesis of 1-Hexyl-3-Methyl-Imidazolium Iodide [HMIM]I}

A mixture of imidazole $(6.8 \mathrm{~g}, 100 \mathrm{mmol})$, 1-Iodehexane $(16.5 \mathrm{~g}, 14 \mathrm{~mL}, 100 \mathrm{mmol})$ and $\mathrm{K}_{2} \mathrm{CO}_{3}$ $(27.6 \mathrm{~g}, 200 \mathrm{mmol})$ in acetone $(200 \mathrm{~mL})$ was refluxed overnight. Upon filtration and removal of solvent, the residue was subjected to flash chromatography with ethyl acetate to give 1-hexyl- $1 \mathrm{H}$-imidazole product with $85 \%$ yield $(12.9 \mathrm{~g})$. Then a mixture of 1 -hexyl- $1 \mathrm{H}$-imidazole $(3 \mathrm{~g}, 20 \mathrm{mmol})$ and iodomethane ( $3.1 \mathrm{~g}, 1.4 \mathrm{~mL}, 22 \mathrm{mmol}$ ) solvent-free was microwaved to $200 \mathrm{MW}$ and a temperature of $80^{\circ} \mathrm{C}$ for $5 \mathrm{~min}$ of reaction (optimum reaction condition). The completion of the reaction was marked by the separation of dense IL. The product was isolated by decanting ethyl acetate to remove any unreacted starting materials and solvent. Subsequently, the IL was washed with diethyl ether $(4 \mathrm{~mL} \times$ $10 \mathrm{~mL}$ ) and the ether layer was separated from the IL by decantation. The IL was finally dried under reduced pressure to get rid of the volatile organic compounds to give [HMIM]I in a 95\% yield (5.6 g).

\subsection{General Procedure for the Synthesis of Indeno[2,1-e]Pyrazolo[5,4-b]Pyridines}

To a $50 \mathrm{~mL}$ round-bottomed flask containing 3-methyl-1-phenyl-1H-pyrazol-5-amine (1 mmol), and aldehyde $(1 \mathrm{mmol})$ and 1,3-indanedione $(1 \mathrm{mmol})$ in $10 \mathrm{~mL}$ water, [HMIM]I (10 mol\%) was added. The solution was irradiated at room temperature by ultrasound for a specified number of minutes. After the completion of the reaction, as indicated by TLC, then the mixture resulting was centrifugated and the obtained product was filtered and dried and if necessary was purified by column chromatography on silica gel to give the pure product. The recovered [HMIM]I-water solution was reused for subsequent runs.

4a: 3-methyl-1-phenyl-4-(pyridin-3-yl)indeno[1,2-b]pyrazolo[4,3-e]pyridin-5(1H)-one. Yield: 95\% (368.7 mg); yellow solid, $\mathrm{mp} 214-216{ }^{\circ} \mathrm{C}$; IR $\left(\mathrm{KBr}, \mathrm{cm}^{-1}\right)$ : 3050, 1751, 1658, 1615, 1514, 1482, 1418, 1328, 1268, 1195, 1097,1016, $758{ }^{1} \mathrm{H}$ NMR $\left(400 \mathrm{MHz},\left(\mathrm{CD}_{3} \mathrm{Cl}\right) 2.07(\mathrm{~s}, 3 \mathrm{H}), 7.34(\mathrm{t}, J=8.0 \mathrm{~Hz}, 1 \mathrm{H}), 7.41(\mathrm{t}\right.$, $J=8.0 \mathrm{~Hz}, 1 \mathrm{H}) 7.50-760(\mathrm{~m}, 5 \mathrm{H}), 7.84(\mathrm{~d}, J=8.0 \mathrm{~Hz}, 1 \mathrm{H}), 7.94(\mathrm{~d}, J=8.0 \mathrm{~Hz}, 1 \mathrm{H}), 8.27(\mathrm{~d}, J=8.0 \mathrm{~Hz}$, 1H), $8.74(\mathrm{~d}, J=8.0 \mathrm{~Hz}, 1 \mathrm{H}) ;{ }^{13} \mathrm{C}$ NMR $\left(100 \mathrm{MHz}, \mathrm{CD}_{3} \mathrm{Cl}\right) ; 15.0\left(\mathrm{CH}_{3}\right), 115.2(\mathrm{C}), 120.1(\mathrm{C}), 121.5(2 \times$ $\mathrm{CH}), 122.6(\mathrm{CH}), 123.5(\mathrm{CH}), 126.5(\mathrm{CH}), 128.6(\mathrm{CH}), 129.0(2 \times \mathrm{CH}), 131.6(\mathrm{CH}), 134.8(\mathrm{CH}), 136.5(\mathrm{CH})$, 
$137.1(\mathrm{C}), 138.7$ (C), 141.5 (C), $142.2(\mathrm{C}), 145.3(\mathrm{C}), 149.0(\mathrm{CH}), 150.3(\mathrm{CH}), 152.6$ (C), 164.9 (C), 189.7 (C); HRMS (ESI, $\mathrm{m} / \mathrm{z}$ ): Calcd for $\mathrm{C}_{25} \mathrm{H}_{16} \mathrm{~N}_{4} \mathrm{OK}[\mathrm{M}+\mathrm{K}]^{+} 427.0961$ found 427.1105 . These spectroscopic data correspond to the previously reported data $[18,19]$.

4b: 4-(3-methyl-5-oxo-1-phenyl-1,5-dihydroindeno[1,2-b]pyrazolo[4,3-e]pyridin-4-yl)benzonitrile Yield: $53 \%$ (218.4 mg); yellow solid, $\mathrm{mp}>300{ }^{\circ} \mathrm{C}$; IR $\left(\mathrm{KBr}, \mathrm{cm}^{-1}\right)$ : 3053, 2938, 1703, 1606, 1549, 1510, 1463 , 1381, 1287, 1261, 1195, 1122, 965, 815, 762; ${ }^{1} \mathrm{H}$ NMR $\left(400 \mathrm{MHz},\left(\mathrm{CD}_{3} \mathrm{Cl}\right) 2.12(\mathrm{~s}, 3 \mathrm{H}), 7.27(\mathrm{t}, J=8.0 \mathrm{~Hz}\right.$, $1 \mathrm{H}), 7.44(\mathrm{t}, J=8.0 \mathrm{~Hz}, 1 \mathrm{H}), 7.54-7.64(\mathrm{~m}, 6 \mathrm{H}), 7.88(\mathrm{~d}, J=8.0 \mathrm{~Hz}, 2 \mathrm{H}), 8.07(\mathrm{~d}, J=8.0 \mathrm{~Hz}, 1 \mathrm{H}), 8.37(\mathrm{~d}$, $J=8.0 \mathrm{~Hz}, 2 \mathrm{H}) ;{ }^{13} \mathrm{C}$ NMR $\left(100 \mathrm{MHz}, \mathrm{CD}_{3} \mathrm{Cl}\right) ; 14.9\left(\mathrm{CH}_{3}\right), 115.2(\mathrm{C}), 118.1(\mathrm{C}), 1190(\mathrm{C}), 121.1(2 \times \mathrm{CH})$, $121.8(\mathrm{CH}), 125.5(\mathrm{CH}), 126.7(2 \times \mathrm{CH}), 129.3(2 \times \mathrm{CH}), 129.50(2 \times \mathrm{CH}), 131.5(\mathrm{CH}), 132.7(\mathrm{CH}), 134.8(\mathrm{C})$, 135.7 (C), 135.3 (C), 139.2 (C), 142.3 (C), 143. 8 (C), 146.2 (C), 153.4 (C), 162.3 (C), 190.2 (C); HRMS (ESI, $\mathrm{m} / \mathrm{z}$ ): Calcd for $\mathrm{C}_{27} \mathrm{H}_{16} \mathrm{~N}_{4} \mathrm{ONa}[\mathrm{M}+\mathrm{Na}]^{+} 435,1222$ found 435.1021 .

4c: 3-(3-methyl-5-oxo-1-phenyl-1,5-dihydroindeno[1,2-b]pyrazolo[4,3-e]pyridin-4-yl)benzonitrile Yield: $64 \%$ (263.8 mg); yellow solid, mp 295-297 ${ }^{\circ} \mathrm{C} \mathrm{IR}\left(\mathrm{KBr}, \mathrm{cm}^{-1}\right)$ : 3062, 2231, 1667, 1595, 1508, 1485, 1328, $1268,1204,1120,1022,854,755 ;{ }^{1} \mathrm{H}$ NMR $\left(400 \mathrm{MHz},\left(\mathrm{CD}_{3} \mathrm{Cl}\right) 1.81(\mathrm{~s}, 3 \mathrm{H}), 7.15-7.41(\mathrm{~m}, 8 \mathrm{H}), 7.61(\mathrm{~d}\right.$, $J=8.0 \mathrm{~Hz}, 2 \mathrm{H}), 7.76(\mathrm{~d}, J=8.0 \mathrm{~Hz}, 1 \mathrm{H}), 8.06(\mathrm{~d}, J=8.0 \mathrm{~Hz}, 1 \mathrm{H}) ;{ }^{13} \mathrm{C} \mathrm{NMR}\left(100 \mathrm{MHz}, \mathrm{CD}_{3} \mathrm{Cl}\right) ; 14.8$ $\left(\mathrm{CH}_{3}\right), 113.1(\mathrm{C}), 114.7(\mathrm{C}), 118.4(\mathrm{C}), 119.7(\mathrm{C}), 121.6(\mathrm{CH}), 121 .(2 \times \mathrm{CH}), 123.6(\mathrm{CH}), 126.6(\mathrm{C}), 129.1$ $(2 \times \mathrm{CH}), 129.5(2 \times \mathrm{CH}), 131.8(\mathrm{CH}), 131.8(2 \times \mathrm{CH}), 135.0(\mathrm{CH}), 137.1(\mathrm{C}), 137.6(\mathrm{C}), 138.7(\mathrm{C}), 142.3$ (C), 142.8 (C), 145.1 (C), 152.7 (C), 164.9 (C), 189.6(C); HRMS (ESI, m/z): Calcd for $\mathrm{C}_{27} \mathrm{H}_{16} \mathrm{~N}_{4} \mathrm{O}[\mathrm{M}]^{+}$ 412.1324 found 412.1213 .

4d: 3-methyl-1-phenyl-4-(quinolin-3-yl)indeno[1,2-b]pyrazolo[4,3-e]pyridin-5(1H)-one. Yield: 27\% (118.3 mg); yellow solid, $\mathrm{mp} \mathrm{200-202}{ }^{\circ} \mathrm{C} \mathrm{IR}\left(\mathrm{KBr}, \mathrm{cm}^{-1}\right)$ : 3058, 1793, 1737, 1602, 1511, 1384, 1251, 1126, 1031, 979, 906, 866, $756{ }^{1} \mathrm{H}$ NMR $\left(400 \mathrm{MHz},\left(\mathrm{CD}_{3} \mathrm{Cl}\right) 2.09(\mathrm{~s}, 3 \mathrm{H}), 6.70(\mathrm{~s}, 1 \mathrm{H}), 7.36(\mathrm{t}, J=8.0 \mathrm{~Hz}, 1 \mathrm{H})\right.$, $7.43(\mathrm{t}, J=8.0 \mathrm{~Hz}, 1 \mathrm{H}), 7.60(\mathrm{~m}, 5 \mathrm{H}), 7.83(\mathrm{t}, J=8.4 \mathrm{~Hz}, 1 \mathrm{H}), 7.92(J=8.1 \mathrm{~Hz}, 1 \mathrm{H}), 7.99(\mathrm{~d}, J=7.3 \mathrm{~Hz}$, $1 \mathrm{H}), 8.24(\mathrm{~d}, J=8.0 \mathrm{~Hz}, 1 \mathrm{H}), 8.32(\mathrm{~m}, 3 \mathrm{H}), 9.01(\mathrm{~d}, J=2.2 \mathrm{~Hz}, 1 \mathrm{H}) ;{ }^{13} \mathrm{C} \mathrm{NMR}\left(100 \mathrm{MHz}, \mathrm{CD}_{3} \mathrm{Cl}\right) ; 15.3$ $\left(\mathrm{CH}_{3}\right), 115.5(\mathrm{C}), 120.4(\mathrm{C}), 121.6(\mathrm{CH}), 121.7(2 \times \mathrm{CH}), 123.6(\mathrm{CH}), 125.7(\mathrm{C}), 126.6(\mathrm{CH}), 126.8(\mathrm{C}), 127.3$ $(\mathrm{CH}), 128.2(\mathrm{CH}), 129.1(2 \times \mathrm{CH}), 129.6(\mathrm{CH}), 130.5(\mathrm{CH}), 131.7(\mathrm{CH}), 134.9(\mathrm{CH}), 136.5(\mathrm{CH}), 137.2(\mathrm{C})$, 138.8 (C), 141.9 (C), 142.3 (C), 145.4 (C), 148.1 (C), 149.7 (CH), 152.8 (C), 165.1 (C), 189.8 (C); HRMS (ESI, $\mathrm{m} / \mathrm{z}$ ): Calcd for $\mathrm{C}_{29} \mathrm{H}_{19} \mathrm{~N}_{4} \mathrm{O}[\mathrm{M}+\mathrm{H}]^{+} 439.1559$ found 439.1572 .

4e: 3-methyl-4-(1-methyl-1H-imidazol-2-yl)-1-phenylindeno[1,2-b]pyrazolo[4,3-e]pyridin-5(1H)-one Yield: 69\% (269.9 mg); yellow solid, mp 303-305 ${ }^{\circ} \mathrm{C}$; IR (KBr, cm $\left.{ }^{-1}\right)$ : 3097, 3062, 2952, 1612, 1592, 1505, 1415, 1256, 1210, 1111, 1016, 889, 750; ${ }^{1} \mathrm{H}$ NMR $\left(400 \mathrm{MHz},\left(\mathrm{CD}_{3} \mathrm{Cl}\right) 2.20(\mathrm{~s}, 3 \mathrm{H}), 3.58(\mathrm{~s}, 3 \mathrm{H}), 7.17(\mathrm{~s}, 1 \mathrm{H})\right.$, $7.30(\mathrm{~s}, 1 \mathrm{H}), 7.36(\mathrm{t}, J=8.0 \mathrm{~Hz}, 1 \mathrm{H}), 7.47(\mathrm{t}, J=8.0 \mathrm{~Hz}, 1 \mathrm{H}), 7.55(\mathrm{t}, J=8.0 \mathrm{~Hz}, 1 \mathrm{H}), 7.63(\mathrm{~d}, J=8.0 \mathrm{~Hz}, 1 \mathrm{H})$, $7.68(\mathrm{~d}, J=8.0 \mathrm{~Hz}, 1 \mathrm{H}), 8.01(\mathrm{~d}, J=8.0 \mathrm{~Hz}, 2 \mathrm{H}), 8.28(\mathrm{~d}, J=8.0 \mathrm{~Hz}, 2 \mathrm{H}) ;{ }^{13} \mathrm{C}$ NMR $\left(100 \mathrm{MHz}, \mathrm{CD}_{3} \mathrm{Cl}\right)$; $13.9\left(\mathrm{CH}_{3}\right), 33.6\left(\mathrm{CH}_{3}\right), 108.2(\mathrm{C}), 116.2(\mathrm{C}), 121.7(2 \times \mathrm{CH}), 121.8(\mathrm{CH}), 122.0(\mathrm{CH}), 123.7(\mathrm{CH}), 126.5$ $(\mathrm{CH}), 129.0(2 \times \mathrm{CH}), 129.4(\mathrm{CH}), 131.7(\mathrm{CH}), 135.1(\mathrm{C}), 137.2(\mathrm{CH}), 138.8(\mathrm{C}), 139.2(\mathrm{C}), 142.6(\mathrm{C}), 146.2$ (C), 164.6 (C), 189.5 (C); HRMS (ESI, m/z): Calcd for $\mathrm{C}_{24} \mathrm{H}_{17} \mathrm{~N}_{5} \mathrm{OK}[\mathrm{M}+\mathrm{K}]^{+} 430.1070$ found 430.1245.

4f: 4-(3-methyl-5-oxo-1-phenyl-1,5-dihydroindeno[1,2-b]pyrazolo[4,3-e]pyridin-4-yl)benzoic acid. Yield: $32 \%$ (137.9 mg); yellow solid, $\mathrm{mp} 274-276{ }^{\circ} \mathrm{C}$; $\mathrm{IR}\left(\mathrm{KBr}, \mathrm{cm}^{-1}\right)$ : 3062, 2955, 2920, 2894, 2851, 1664 , $1589,1508,1421,1378,1184,1114,923 ;{ }^{1} \mathrm{H}$ NMR $\left(400 \mathrm{MHz},\left(\mathrm{CD}_{3} \mathrm{Cl}\right) 2.06(\mathrm{~s}, 3 \mathrm{H}), 7.38(\mathrm{t}, J=8.0 \mathrm{~Hz}\right.$, $1 \mathrm{H}), 7.46(\mathrm{t}, J=8.0 \mathrm{~Hz}, 1 \mathrm{H}), 7.57(\mathrm{t}, J=8.0 \mathrm{~Hz}, 2 \mathrm{H}), 7.60-7.64(\mathrm{~m}, 3 \mathrm{H}), 8.01(\mathrm{~d}, J=8.0 \mathrm{~Hz}, 1 \mathrm{H}), 8.07(\mathrm{~d}$, $J=8.0 \mathrm{~Hz}, 1 \mathrm{H}), 8.30(\mathrm{~d}, J=8.0 \mathrm{~Hz}, 2 \mathrm{H}), 10.16(\mathrm{~s}, 1 \mathrm{H}) ;{ }^{13} \mathrm{C} \mathrm{NMR}\left(100 \mathrm{MHz}, \mathrm{CD}_{3} \mathrm{Cl}\right) ; 14.8\left(\mathrm{CH}_{3}\right), 114.9$ (C), $119.9(\mathrm{C}), 121.6(\mathrm{CH}), 121.7(2 \times \mathrm{CH}), 123.6(\mathrm{CH}), 126.6(\mathrm{CH}), 129.1(2 \times \mathrm{CH}), 129.4(2 \times \mathrm{CH}), 129.5$ $(2 \times \mathrm{CH}), 131.7(\mathrm{CH}), 134.9(\mathrm{CH}), 136.7(\mathrm{C}), 137.2(\mathrm{C}), 138.8(\mathrm{C}), 139.1(\mathrm{C}), 142.3(\mathrm{C}), 143.8(\mathrm{C}), 145.4$ (C), 152.7 (C), 165.0 (C), 189.7 (C), 191.7 (CH); HRMS (ESI, m/z): Calcd for $\mathrm{C}_{27} \mathrm{H}_{17} \mathrm{~N}_{3} \mathrm{O}_{3} \mathrm{Na}[\mathrm{M}+\mathrm{Na}]^{+}$ 454.1168 found 454.1354 .

4g: 3-Methyl-1-phenylindeno[2,3-e]pyrazolo[3,4-b]pyridin-5(1H)-one [58]. Yield: 65\% (220.9 mg); yellow solid; mp 246-248 ${ }^{\circ} \mathrm{C}$; IR $\left(\mathrm{KBr}, \mathrm{cm}^{-1}\right)$ : 3390, 3054, 2923, 1716, 1613, 1589, 1502, 1337, 1290, 1138, 1028, 809, 781, 727, 636, 553; ${ }^{1} \mathrm{H}$ NMR (400 MHz, DMSO-d6): 2.61 (s, 3H, $\left.\mathrm{CH}_{3}\right), 7.38(\mathrm{t}, J=7.4 \mathrm{~Hz}, 1 \mathrm{H})$, 
$7.95(\mathrm{~d}, J=7.2 \mathrm{~Hz}, 1 \mathrm{H}), 8.28(\mathrm{~d}, J=7.7 \mathrm{~Hz}, 2 \mathrm{H}), 8.47(\mathrm{~s}, 1 \mathrm{H}) ;{ }^{13} \mathrm{CNMR}(100 \mathrm{MHz}, \mathrm{DMSO}-\mathrm{d} 6) 11.3\left(\mathrm{CH}_{3}\right)$, $116.0(\mathrm{C}), 120.5(2 \times \mathrm{CH}), 120.7(\mathrm{CH}), 122.6(\mathrm{C}), 122.9(\mathrm{CH}), 125.7(\mathrm{CH}), 126.4(\mathrm{CH}), 128.5(2 \times \mathrm{CH}), 131.3$ (CH), $134.8(\mathrm{CH}), 136.3$ (C), 138.3 (C), 141.8 (C), 145.5 (C), 152.2 (C), 163.5 (C), 188.9 (C); HRMS (ESI, $\mathrm{m} / \mathrm{z}$ ): calcd for $\mathrm{C}_{20} \mathrm{H}_{13} \mathrm{~N}_{3} \mathrm{OK}[\mathrm{M}+\mathrm{K}]^{+} 350.4350$ found 349.4350 .

4h: 4-(furan-2-yl)-3-methyl-1-phenylindeno[1,2-b]pyrazolo[4,3-e]pyridin-5(1H)-one. Yield: 78\% (294.1 mg); yellow solid, $\mathrm{mp} 200-202{ }^{\circ} \mathrm{C}$ IR $\left(\mathrm{KBr}, \mathrm{cm}^{-1}\right)$ : 3053, 2923 1742, 1658, 1664, 1609, 1545, 1499, 1317, 1265 , 1198, 1068, 961, 880; ${ }^{1} \mathrm{H}$ NMR $\left(400 \mathrm{MHz},\left(\mathrm{CD}_{3} \mathrm{Cl}\right) 2.46(\mathrm{~s}, 3 \mathrm{H}), 6.70(\mathrm{~s}, 1 \mathrm{H}), 7.34(\mathrm{t}, J=8.0 \mathrm{~Hz}, 1 \mathrm{H}), 7.42(\mathrm{t}\right.$, $J=8.0 \mathrm{~Hz}, 1 \mathrm{H}), 7.53(\mathrm{~m}, 4 \mathrm{H}), 7.65(\mathrm{t}, J=7.3 \mathrm{~Hz}, 1 \mathrm{H}), 7.71(\mathrm{~s}, 1 \mathrm{H}), 7.89(\mathrm{~d}, J=7.3 \mathrm{~Hz}, 1 \mathrm{H}), 8.26(\mathrm{~d}, J=8.0 \mathrm{~Hz}$, 2H); ${ }^{13} \mathrm{C}$ NMR (100 MHz, CD $\left.{ }_{3} \mathrm{Cl}\right) ; 16.0\left(\mathrm{CH}_{3}\right), 112.3(\mathrm{CH}), 113.7(\mathrm{C}), 117.2(\mathrm{CH}), 118.1(\mathrm{C}), 121.2(\mathrm{CH})$, $121.6(2 \times \mathrm{CH}), 123.3(\mathrm{CH}), 126.3(\mathrm{CH}), 128.9(2 \times \mathrm{CH}), 131.4(\mathrm{CH}), 133.0(\mathrm{C}), 134.5(\mathrm{CH}), 137.3(\mathrm{C}), 138.8$ (C), 141.9 (C), 144.1 (CH), 145.1 (C), 146.0 (C), 153.1 (C), 165.0 (C), 189.4 (C); HRMS (ESI, m/z): Calcd for $\mathrm{C}_{24} \mathrm{H}_{15} \mathrm{~N}_{3} \mathrm{O}_{2} \mathrm{~K}[\mathrm{M}+\mathrm{K}]^{+} 416.0801$ found 416.1132 .

4i: N,N-dimethyl-4-(3-methyl-1-phenyl-1,5-dihydroindeno[1,2-b]pyrazolo[4,3-e]pyridin-4-yl)aniline. Yield: $63 \%$ (262.4 mg); green solid, $\mathrm{mp} 198-200{ }^{\circ} \mathrm{C} ;{ }^{1} \mathrm{H}$ NMR $\left(400 \mathrm{MHz},\left(\mathrm{CD}_{3} \mathrm{Cl}\right) ; 2.14(\mathrm{~s}, 3 \mathrm{H}), 2.94(\mathrm{~s}\right.$, $6 \mathrm{H}), 3.68(\mathrm{~s}, 2 \mathrm{H}), 6.72(\mathrm{~d}, J=8.0 \mathrm{~Hz}, 2 \mathrm{H}), 7.17(\mathrm{~m}, 1 \mathrm{H}), 7.23(\mathrm{~d}, J=8.0 \mathrm{~Hz}, 2 \mathrm{H}), 7.29(\mathrm{~d}, J=8.0 \mathrm{~Hz}, 1 \mathrm{H})$, $7.35(\mathrm{~m}, 3 \mathrm{H}), 7.43(\mathrm{t}, J=8.0 \mathrm{~Hz}, 3 \mathrm{H}), 8.11(\mathrm{~d}, J=8.0 \mathrm{~Hz}, 1 \mathrm{H})$; HRMS (ESI, m/z): Calcd for $\mathrm{C}_{28} \mathrm{H}_{24} \mathrm{~N}_{4}$ $[\mathrm{M}]^{+}$416,2001 found 416,2122.

4j: Ethyl4-(4-(dimethylamino)phenyl)-3,6-dimethyl-1-phenyl-1H-pyrazolo[3,4-b]pyridine-5-carboxylate. Yield: $71 \%$ (294.3 mg); orange crystals, mp $167-169^{\circ} \mathrm{C}$; IR (KBr, cm $\left.{ }^{-1}\right): 2975,2885,1728,1612,1528$, 1430, 1239, 1204, 1106, 822, 744; ${ }^{1} \mathrm{H}$ NMR $\left(400 \mathrm{MHz},\left(\mathrm{CD}_{3} \mathrm{Cl}\right) ; 1.06(\mathrm{t}, J=7.0 \mathrm{~Hz}, 3 \mathrm{H}), 2.18(\mathrm{~s}, 3 \mathrm{H}), 2.73\right.$ $(\mathrm{s}, 3 \mathrm{H}), 3.03(\mathrm{~s}, 6 \mathrm{H}), 4.12(\mathrm{q}, J=7.0 \mathrm{~Hz}, 2 \mathrm{H}), 6.78(\mathrm{~d}, J=8.0 \mathrm{~Hz}, 2 \mathrm{H}), 7.27-7.30(\mathrm{~m}, 3 \mathrm{H}), 7.51(\mathrm{t}, J=8.0$ $\mathrm{Hz}, 2 \mathrm{H}), 8.30(\mathrm{~d}, \mathrm{~J}=8.0 \mathrm{~Hz}, 2 \mathrm{H}) ;{ }^{13} \mathrm{C} \mathrm{NMR}\left(100 \mathrm{MHz}, \mathrm{CD}_{3} \mathrm{Cl}\right) ;{ }^{13} \mathrm{C} \mathrm{NMR}\left(100 \mathrm{MHz}, \mathrm{CD}_{3} \mathrm{Cl}\right) ; 13.8$ $\left(\mathrm{CH}_{3}\right), 14.9\left(\mathrm{CH}_{3}\right), 23.7\left(\mathrm{CH}_{3}\right), 40.3\left(2 \times \mathrm{CH}_{3}\right), 61.1\left(\mathrm{CH}_{2}\right), 111.4(2 \times \mathrm{CH}), 113.4(\mathrm{C}), 121.0(2 \times \mathrm{CH})$, $122.7(\mathrm{C}), 124.2(\mathrm{C}), 125.5(\mathrm{CH}), 128.9(2 \times \mathrm{CH}), 129.7(2 \times \mathrm{CH}), 139.4(\mathrm{C}), 143.7(\mathrm{C}), 144.7(\mathrm{C}), 150.2(\mathrm{C})$, 150.5 (C), 155.4 (C), 169.2 (C); HRMS (ESI, m/z): Calcd for $\mathrm{C}_{25} \mathrm{H}_{26} \mathrm{~N}_{4} \mathrm{O}_{2}[\mathrm{M}]^{+} 414.2056$ found 414.2055.

4k: 1-(3,6-dimethyl-4-(pyridin-3-yl)-1H-pyrazolo[3,4-b]pyridin-5-yl)ethan-1-one. Yield: 49\% (130.5 mg); beige solid, $\mathrm{mp} 168-170{ }^{\circ} \mathrm{C}$; IR $\left(\mathrm{KBr}, \mathrm{cm}^{-1}\right)$ : 3386, 2932, 1618, 1574, 1525, 14441, 1369, 1233, 1025, 834, 700; ${ }^{1} \mathrm{H}$ NMR (400 MHz, $\left(\mathrm{CD}_{3} \mathrm{Cl}\right) ; 2.40(\mathrm{~s}, 3 \mathrm{H}), 2.42(\mathrm{~s}, 3 \mathrm{H}), 2.65(\mathrm{~s}, 3 \mathrm{H}), 6.30(\mathrm{~s}, 1 \mathrm{H}), 6.40(\mathrm{~s}, 1 \mathrm{H}), 7.17$ $(\mathrm{dd}, J=8.0,4.9 \mathrm{~Hz}, 2 \mathrm{H}), 7.56(\mathrm{~d}, J=8.0 \mathrm{~Hz}, 2 \mathrm{H}), 8.44(\mathrm{~m}, 1 \mathrm{H}) ; \mathrm{HRMS}(\mathrm{ESI}, \mathrm{m} / \mathrm{z})$ : Calcd for $\mathrm{C}_{15} \mathrm{H}_{15} \mathrm{~N}_{4} \mathrm{O}$ $[\mathrm{M}+\mathrm{H}]^{+} 267,1246$ found 267,1223 .

5a: 2-((1H-pyrrol-3-yl)methylene)-1H-indene-1,3(2H)-dione. Yield: 61\% (136.2 mg); Green solid, mp 158-160 ${ }^{\circ} \mathrm{C}$; IR $\left(\mathrm{KBr}, \mathrm{cm}^{-1}\right)$ : 1713, 1655, 1577, 1326, 1218, 1149, 1077, 758, 735, 591; ${ }^{1} \mathrm{H}$ NMR $(400 \mathrm{MHz}$, $\left(\mathrm{CD}_{3} \mathrm{Cl}\right) 6.47(\mathrm{~s}, 1 \mathrm{H}), 7.02(\mathrm{~s}, 1 \mathrm{H}), 7.34(\mathrm{bs}, 1 \mathrm{H}), 7.67(\mathrm{~s}, 1 \mathrm{H}), 7.71(\mathrm{~m}, 2 \mathrm{H}), 7.88(\mathrm{~m}, 2 \mathrm{H}), 13.10(\mathrm{bs}, 1 \mathrm{H})$; ${ }^{13} \mathrm{C}$ NMR $\left(100 \mathrm{MHz}, \mathrm{CD}_{3} \mathrm{Cl}\right) 114.2(\mathrm{CH}), 120.0(\mathrm{C}), 122.6(2 \times \mathrm{CH}), 126.5(\mathrm{CH}), 129.6(\mathrm{CH}), 130.6(\mathrm{C})$, $133.1(\mathrm{CH}), 134.4(\mathrm{CH}), 134.7(\mathrm{CH}), 140.2(\mathrm{C}), 141.1(\mathrm{C}), 190.6$ (C), 192.1 (C); HRMS (ESI, m/z): Calcd for $\mathrm{C}_{14} \mathrm{H}_{9} \mathrm{NO}_{2}[\mathrm{M}]^{+} 223.0633$ found 223.0631. These spectroscopic data correspond to the previously reported data [59-61].

5b: 2-(4-morpholinobenzylidene)-1H-indene-1,3(2H)-dione. Yield: 81\% (258.7 mg); red solid, mp 257-259 ${ }^{\circ} \mathrm{C}$; IR $\left(\mathrm{KBr}, \mathrm{cm}^{-1}\right)$ : 2955, 2839, 1719, 1658, 1566, 1514, 1383, 1242, 1109, 1033, 923, 724; ${ }^{1} \mathrm{H}$ NMR $\left(400 \mathrm{MHz},\left(\mathrm{CD}_{3} \mathrm{Cl}\right) 3.43(\mathrm{~m}, 4 \mathrm{H}), 3.87(\mathrm{~m}, 4 \mathrm{H}), 8.92(\mathrm{~d}, J=8.0 \mathrm{~Hz}, 2 \mathrm{H}), 7.75(\mathrm{~m}, 2 \mathrm{H}), 7.79(\mathrm{~s}, 1 \mathrm{H}), 7.95(\mathrm{~m}\right.$, $2 \mathrm{H}), 8.53(\mathrm{~d}, J=8.0 \mathrm{~Hz}, 2 \mathrm{H}) ;{ }^{13} \mathrm{C} \mathrm{NMR}\left(100 \mathrm{MHz}, \mathrm{CD}_{3} \mathrm{Cl}\right) ; 46.8(2 \times \mathrm{CH} 2), 66.4(2 \times \mathrm{CH} 2), 113.1(\mathrm{CH}$ $\times 2), 122.7(\mathrm{CH} \times 2), 124.0(\mathrm{C}), 124.7(\mathrm{C}), 134.4(\mathrm{CH}), 134.6(\mathrm{CH}), 137.5(\mathrm{CH} \times 2), 139.9(\mathrm{C}), 142.3(\mathrm{C})$, $146.9(\mathrm{CH}), 154.2(\mathrm{C}), 189.8$ (C), 191.3 (C); HRMS (ESI, m/z): Calcd for $\mathrm{C}_{20} \mathrm{H}_{17} \mathrm{NO}_{3}[\mathrm{M}]^{+} 319.1208$ found 319.1211. These spectroscopic data correspond to the previously reported data [62].

5c: 3-((1,3-dioxo-1,3-dihydro-2H-inden-2-ylidene)methyl)benzonitrile. Yield: 74\% (191.7 mg); yellow solid, mp 257-259 ${ }^{\circ} \mathrm{C}$; IR ( $\left.\mathrm{KBr}, \mathrm{cm}^{-1}\right)$ : 2955, 2839, 1719, 1658, 1566, 1514, 1383, 1242, 1109, 1033, 923, 724; ${ }^{1} \mathrm{H}$ NMR $(400 \mathrm{MHz}, \mathrm{CD} 3 \mathrm{Cl}) ; 7.16(\mathrm{t}, J=8.0 \mathrm{~Hz}, 1 \mathrm{H}), 7.88(\mathrm{~s}, 1 \mathrm{H}), 7.98-8.05(\mathrm{~m}, 5 \mathrm{H}), 8.66(\mathrm{~d}, J=8.0 \mathrm{~Hz}$, 
1H), $8.92(\mathrm{~s}, 1 \mathrm{H}) ;{ }^{13} \mathrm{C} \mathrm{NMR}\left(100 \mathrm{MHz}, \mathrm{CD}_{3} \mathrm{Cl}\right) ; 112.2(\mathrm{C}), 118.7(\mathrm{C}), 123.7(\mathrm{CH}), 123.8(\mathrm{CH}), 130.4(\mathrm{CH})$, $131.8(\mathrm{C}), 134.1(\mathrm{C}), 135.9(\mathrm{CH}), 136.6(\mathrm{CH}), 136.7(\mathrm{CH}), 136.8(\mathrm{CH}), 138.1(\mathrm{CH}), 140.1(\mathrm{C}), 142.5(\mathrm{C}), 142.7$ $(\mathrm{CH}), 188.9(\mathrm{C}), 189.3(\mathrm{C})$. These spectroscopic data correspond to the previously reported data $[63,64]$.

\section{Computational Details}

All the structures included in this study were optimized at B3LYP/6-31G(d) [65] theory level by using the Gaussian09 package [66]. The densities, used in the new methodology, were calculated at the same level of calculation for the neutral molecule, the cation and anion, through Gaussian09 software. The bond reactivity indices used in this study were calculated with UCA-FUKUI v.2.1 software (http://www2.uca.es/dept/quimica_fisica/software/UCA-FUKUI_v2.exe) [67]. Natural bond orbital images were built using GaussView program [68].

\section{Biological Evaluation}

The inhibitory potency of the compounds as AChE inhibitors was evaluated from Electrophorus electricus, with galantamine as reference compound. The selectivity was estimated with the inhibition of the derivatives over butyrylcholinesterase (BuChE). Both inhibitory activities were evaluated by the method of Ellman et al [54]. All compounds were evaluated as antibacterial agents using the microdilution methods [57].

\section{Conclusions}

In conclusion, we reported a simple, highly efficient, and environmentally benign protocol for the synthesis of pyrazolo-fused 4-azafluorenones (indeno[1,2-b]pyrazolo[4,3-e]pyridines, IPP) through a multi-component reaction in IL by one-pot three-component condensation of arylaldehydes, 3-methyl-1H-pyrazol-5-amine, and 1,3-indanedione in an ionic liquid as a catalyst at room temperature using sonochemical energy. This methodology has advantages of moderate yields in shorter reaction times, the IL could be readily recovered and reused for several consecutive cycles, simple experimental, and work-up procedures. We believe that this method will be more useful than the existing literature methods for the synthesis of pyrazolo-fused 4-azafluorenones. A theoretical study, based on bond reactivity indices, confirmed the proposed mechanism. The electrophilic and nucleophilic character of localized orbitals was determined to obtain a reasonable mechanism. Finally, the biological potential of the series of compounds was shown.

Author Contributions: Synthetic Methodology E.P., O.F.-D. and V.A.-P., Bioinformatic analysis X.A.L.-C. Biological activity V.A.-P. and M.G. Writing-original draft E.P. and O.F.-D., Writing-review and editing E.P. and M.G., Resources M.G.

Funding: This research received no external funding.

Acknowledgments: Efrain Polo thanks to CONICYT Fellowship No. 63140046; Margarita Gutierrez thanks FONDECYT project number 1150712, Oscar Forero-Doria Thanks to FONDECYT Postdoctoral Fellowship No. 3170757.

Conflicts of Interest: The authors declare no conflict of interest.

\section{References}

1. Addla, D.; Sridhar, B.; Devi, A.; Kantevari, S. Design, synthesis and antimicrobial evaluation of novel 1-benzyl 2-butyl-4-chloroimidazole embodied 4-azafluorenones via molecular hybridization approach. Bioorg. Med. Chem. Lett. 2012, 22, 7475-7480. [CrossRef] [PubMed]

2. Anand, D.; Yadav, P.K.; Patel, O.P.S.; Parmar, N.; Maurya, R.K.; Vishwakarma, P.; Raju, K.S.R.; Taneja, I.; Wahajuddin, M.; Kar, S.; et al. Antileishmanial Activity of Pyrazolopyridine Derivatives and Their Potential as an Adjunct Therapy with Miltefosine. J. Med. Chem. 2017, 60, 1041-1059. [CrossRef] [PubMed]

3. Heintzelman, G.; Averill, K.; Dodd, J.; Demarest, K.; Tang, Y.; Jackson, P. Arylindenopyridines and Related Therapeutic and Prophylactic Methods. U.S. Patent No. 6,903,109, 7 July 2005. 
4. Heintzelman, G.R.; Averill, K.M.; Dodd, J.H.; Demarest, K.T.; Tang, Y.; Jackson, P.F. 5-oxo and 5-thio Derivatives of 5h-Indeno'1,2-Bipyridine with Adenosine a2a Receptor Binding and Phosphodiesterase Inhibiting Activity for the Treatment of Neurodegenerative Disorders and Inflammation Related Diseases. Int. Patent WO 03/088963, 30 October 2003.

5. Safak, C.; Simsek, R.; Altas, Y.; Boydag, S.; Erol, K. 2-methyl-3-acetyl-4-aryl-5-oxo-1,4-dihydro-5H indeno(1,2-b) pyridine derivatives studies and their calcium antagonistic activities. Boll. Chim. Farm. 1997, 136, 665-669. [PubMed]

6. Ashton, M.J.; Cook, D.C.; Fenton, G.; Karlsson, J.-A.; Palfreyman, M.N.; Raeburn, D.; Ratcliffe, A.J.; Souness, J.E.; Thurairatnam, S.; Vicker, N. Selective Type IV Phosphodiesterase Inhibitors as Antiasthmatic Agents. The Syntheses and Biological Activities of 3-(Cyclopentyloxy)-4-methoxybenzamides and Analogs. J. Med. Chem. 1994, 37, 1696-1703. [CrossRef]

7. Manpadi, M.; Uglinskii, P.Y.; Rastogi, S.K.; Cotter, K.M.; Wong, Y.-S.C.; Anderson, L.A.; Ortega, A.J.; Van slambrouck, S.; Steelant, W.F.A.; Rogelj, S.; et al. Three-component synthesis and anticancer evaluation of polycyclic indenopyridines lead to the discovery of a novel indenoheterocycle with potent apoptosis inducing properties. Org. Biomol. Chem. 2007, 5, 3865. [CrossRef] [PubMed]

8. Prachayasittikul, S.; Manam, P.; Chinworrungsee, M.; Isarankura-Na-Ayudhya, C.; Ruchirawat, S.; Prachayasittikul, V. Bioactive Azafluorenone Alkaloids from Polyalthia debilis (Pierre) Finet \& Gagnep. Molecules 2009, 14, 4414-4424. [PubMed]

9. Wu, Y.-C.; Duh, C.-Y.; Wang, S.-K.; Chen, K.-S.; Yang, T.-H. Two New Natural Azafluorene Alkaloids and a Cytotoxic Aporphine Alkaloid from Polyalthia longifolia. J. Nat. Prod. 1990, 53, 1327-1331. [CrossRef] [PubMed]

10. Naaz, H.; Singh, S.; Pandey, V.P.; Singh, P.; Dwivedi, U.N. Anti-cholinergic alkaloids as potential therapeutic agents for Alzheimer's disease: An in silico approach. Indian J. Biochem. Biophys. 2013, 50, 120-125. [PubMed]

11. Marquise, N.; Harford, P.J.; Chevallier, F.; Roisnel, T.; Dorcet, V.; Gagez, A.-L.; Sablé, S.; Picot, L.; Thiéry, V.; Wheatley, A.E.H.; et al. Synthesis of azafluorenones and related compounds using deprotocuprationaroylation followed by intramolecular direct arylation. Tetrahedron 2013, 69, 10123-10133. [CrossRef]

12. Utsugi, T.; Aoyagi, K.; Asao, T.; Okazaki, S.; Aoyagi, Y.; Sano, M.; Wierzba, K.; Yamada, Y. Antitumor activity of a novel quinoline derivative, TAS-103, with inhibitory effects on topoisomerases I and II. Jpn. J. Cancer Res. Gann 1997, 88, 992-1002. [CrossRef] [PubMed]

13. Petrova, O.N.; Lipson, V.V.; Zamigailo, L.L.; Shirobokova, M.G.; Musatov, V.I.; Baumer, V.N.; Sofronov, D.S. Synthesis and chemical properties of 4-aroyl-3-methyl-4,10-dihydroindeno[1,2-b]pyrazolo-[4,3-e]pyridin-5-ones. Russ. J. Org. Chem. 2015, 51, 1597-1605. [CrossRef]

14. Nikpassand, M.; Mamaghani, M.; Shirini, F.; Tabatabaeian, K. A convenient ultrasound-promoted regioselective synthesis of fused polycyclic 4-aryl-3-methyl-4,7-dihydro-1H-pyrazolo[3,4-b]pyridines. Ultrason. Sonochem. 2010, 17, 301-305. [CrossRef] [PubMed]

15. Shi, F.; Zhang, Y.; Tu, S.-J.; Zhou, D.-X.; Li, C.-M.; Shao, Q.-Q.; Cao, L.-J. A Green Approach to the Synthesis of Biologically Important Indeno[2,1- e ]pyrazolo[5,4- b ]pyridines via Microwave-assisted Multi-component Reactions in Water. Chin. J. Chem. 2008, 26, 1262-1266. [CrossRef]

16. Khurana, J.M.; Chaudhary, A.; Nand, B.; Lumb, A. Aqua mediated indium(III) chloride catalyzed synthesis of fused pyrimidines and pyrazoles. Tetrahedron Lett. 2012, 53, 3018-3022. [CrossRef]

17. Quiroga, J.; Cobo, D.; Insuasty, B.; Abonía, R.; Cruz, S.; Nogueras, M.; Cobo, J. Regioselective three-component synthesis of novel indeno[1,2- b ]-pyrazolo[4,3- e ]pyridines-fused derivatives of 4-azafluorenone alkaloid. J. Heterocycl. Chem. 2008, 45, 155-159. [CrossRef]

18. Shi, C.-L.; Shi, D.-Q.; Kim, S.H.; Huang, Z.-B.; Ji, S.-J.; Ji, M. A novel and efficient one-pot synthesis of furo[3', $\left.4^{\prime}: 5,6\right]$ pyrido[2,3-c]pyrazole derivatives using organocatalysts. Tetrahedron 2008, 64, 2425-2432. [CrossRef]

19. Shi, D.-Q.; Shi, J.-W.; Yao, H. Three-Component One-Pot Synthesis of Indeno[2' $\left., 1^{\prime}: 5,6\right]$ Pyrido[2,3- d ]Pyrazole Derivatives in Aqueous Media. J. Chin. Chem. Soc. 2009, 56, 504-509. [CrossRef]

20. Shi, D.-Q.; Yang, F.; Ni, S.-N. A facile synthesis of furo[3,4- e ]pyrazolo[3,4- b ]pyridine-5(7 H)-one derivatives via three-component reaction in ionic liquid without any catalyst. J. Heterocycl. Chem. 2009, 46, 469-476. [CrossRef]

21. Simon, M.-O.; Li, C.-J. Green chemistry oriented organic synthesis in water. Chem. Soc. Rev. 2012, 41, 1415-1427. [CrossRef] 
22. Dömling, A.; Wang, W.; Wang, K. Chemistry and Biology of Multicomponent Reactions. Chem. Rev. 2012, 112, 3083-3135. [CrossRef]

23. Rotstein, B.H.; Zaretsky, S.; Rai, V.; Yudin, A.K. Small Heterocycles in Multicomponent Reactions. Chem. Rev. 2014, 114, 8323-8359. [CrossRef] [PubMed]

24. Brauch, S.; van Berkel, S.S.; Westermann, B. Higher-order multicomponent reactions: Beyond four reactants. Chem. Soc. Rev. 2013, 42, 4948. [CrossRef] [PubMed]

25. de Graaff, C.; Ruijter, E.; Orru, R.V.A. Recent developments in asymmetric multicomponent reactions. Chem. Soc. Rev. 2012, 41, 3969. [CrossRef] [PubMed]

26. Cintas, P.; Luche, J.-L. Green chemistry. Green Chem. 1999, 1, 115-125. [CrossRef]

27. Constable, D.J.C.; Curzons, A.D.; Cunningham, V.L. Metrics to 'green' chemistry-Which are the best? Green Chem. 2002, 4, 521-527. [CrossRef]

28. Poliakoff, M. Green Chemistry: Science and Politics of Change. Science 2002, 297, 807-810. [CrossRef] [PubMed]

29. Egorova, K.S.; Gordeev, E.G.; Ananikov, V.P. Biological Activity of Ionic Liquids and Their Application in Pharmaceutics and Medicine. Chem. Rev. 2017, 117, 7132-7189. [CrossRef]

30. Xu, L.-W.; Li, J.-W.; Zhou, S.-L.; Xia, C.-G. A green, ionic liquid and quaternary ammonium salt-catalyzed aza-Michael reaction of $\alpha, \beta$-ethylenic compounds with amines in water. New. J. Chem. 2004, 28, 183-184. [CrossRef]

31. Howarth, J. An exploration of the catalytic Sakurai reaction in the moisture stable ionic liquids [bmim]PF6 and [bmim]BF4. J. Mol. Catal. Chem. 2004, 214, 143-146. [CrossRef]

32. Palimkar, S.S.; Siddiqui, S.A.; Daniel, T.; Lahoti, R.J.; Srinivasan, K.V. Ionic Liquid-Promoted Regiospecific Friedlander Annulation: Novel Synthesis of Quinolines and Fused Polycyclic Quinolines. J. Org. Chem. 2003, 68, 9371-9378. [CrossRef]

33. Kabalka, G.W.; Venkataiah, B.; Dong, G. The use of potassium alkynyltrifluoroborates in Mannich reactions. Tetrahedron Lett. 2004, 45, 729-731. [CrossRef]

34. Carmichael, A.J.; Earle, M.J.; Holbrey, J.D.; McCormac, P.B.; Seddon, K.R. The Heck Reaction in Ionic Liquids: A Multiphasic Catalyst System. Org. Lett. 1999, 1, 997-1000. [CrossRef]

35. Mathews, C.J.; Smith, P.J.; Welton, T. Palladium catalysed Suzuki cross-coupling reactions in ambient temperature ionic liquids. Chem. Commun. 2000, 14, 1249-1250. [CrossRef]

36. Schreiner, P.R. Metal-free organocatalysis through explicit hydrogen bonding interactions. Chem. Soc. Rev. 2003, 32, 289. [CrossRef] [PubMed]

37. Rosa, J.N.; Afonso, C.A.M.; Santos, A.G. Ionic liquids as a recyclable reaction medium for the Baylis-Hillman reaction. Tetrahedron 2001, 57, 4189-4193. [CrossRef]

38. Gholap, A.R.; Venkatesan, K.; Daniel, T.; Lahoti, R.J.; Srinivasan, K.V. Ionic liquid promoted novel and efficient one pot synthesis of 3,4-dihydropyrimidin-2-(1H)-ones at ambient temperature under ultrasound irradiation. Green Chem. 2004, 6, 147. [CrossRef]

39. Shelke, K.F.; Madje, B.R.; Sapkal, S.B.; Shingate, B.B.; Shingare, M.S. An efficient ionic liquid promoted Knoevenagel condensation of 4-oxo-4 H -benzopyran-3-carbaldehyde with Meldrum's acid. Green Chem. Lett. Rev. 2009, 2, 3-7. [CrossRef]

40. Karmee, S.K.; Hanefeld, U. Ionic Liquid Catalysed Synthesis of $\beta$-Hydroxy Ketones. ChemSusChem 2011, 4, 1118-1123. [CrossRef]

41. Peng, J.; Deng, Y. Cycloaddition of carbon dioxide to propylene oxide catalyzed by ionic liquids. New J. Chem. 2001, 25, 639-641. [CrossRef]

42. Carmichael, A.J.; Haddleton, D.M.; Bon, S.A.F.; Seddon, K.R. Copper(i) mediated living radical polymerisation in an ionic liquid. Chem. Commun. 2000, 1, 1237-1238. [CrossRef]

43. Khan, F.A.; Dash, J.; Satapathy, R.; Upadhyay, S.K. Hydrotalcite catalysis in ionic liquid medium: A recyclable reaction system for heterogeneous Knoevenagel and nitroaldol condensation. Tetrahedron Lett. 2004, 45, 3055-3058. [CrossRef]

44. Wong, H.; Pink, C.J.; Ferreira, F.C.; Livingston, A.G. Recovery and reuse of ionic liquids and palladium catalyst for Suzuki reactions using organic solvent nanofiltration. Green Chem. 2006, 8, 373. [CrossRef]

45. Hunt, P.A.; Kirchner, B.; Welton, T. Characterising the Electronic Structure of Ionic Liquids: An Examination of the 1-Butyl-3-Methylimidazolium Chloride Ion Pair. Chem. Eur. J. 2006, 12, 6762-6775. [CrossRef] [PubMed] 
46. Weingärtner, H. Understanding Ionic Liquids at the Molecular Level: Facts, Problems, and Controversies. Angew. Chem. Int. Ed. 2008, 47, 654-670. [CrossRef] [PubMed]

47. Sánchez-Márquez, J. Introducing new reactivity descriptors: "Bond reactivity indices." Comparison of the new definitions and atomic reactivity indices. J. Chem. Phys. 2016, 145, 194105. [CrossRef] [PubMed]

48. Sánchez-Márquez, J.; Zorrilla, D.; García, V.; Fernández, M. Introducing a new bond reactivity index: Philicities for natural bond orbitals. J. Mol. Model. 2018, 24, 25. [CrossRef] [PubMed]

49. Morell, C.; Grand, A.; Toro-Labbé, A. New Dual Descriptor for Chemical Reactivity. J. Phys. Chem. A 2005, 109, 205-212. [CrossRef]

50. Reed, A.E.; Curtiss, L.A.; Weinhold, F. Intermolecular interactions from a natural bond orbital, donor-acceptor viewpoint. Chem. Rev. 1988, 88, 899-926. [CrossRef]

51. Glendening, E.D.; Landis, C.R.; Weinhold, F. Natural bond orbital methods: Natural bond orbital methods. Wiley Interdiscip. Rev. Comput. Mol. Sci. 2012, 2, 1-42. [CrossRef]

52. Hirshfeld, F.L. Bonded-atom fragments for describing molecular charge densities. Theor. Chim. Acta 1977, 44, 129-138. [CrossRef]

53. Ritchie, J.P.; Bachrach, S.M. Some methods and applications of electron density distribution analysis. J. Comput. Chem. 1987, 8, 499-509. [CrossRef]

54. Ellman, G.L.; Courtney, K.D.; Andres, V., Jr.; Featherstone, R.M. A new and rapid colorimetric determination of acetylcholinesterase activity. Biochem. Pharmacol. 1961, 7, 88-95. [CrossRef]

55. Friesner, R.A.; Banks, J.L.; Murphy, R.B.; Halgren, T.A.; Klicic, J.J.; Mainz, D.T.; Repasky, M.P.; Knoll, E.H.; Shelley, M.; Perry, J.K.; et al. Glide: A New Approach for Rapid, Accurate Docking and Scoring. 1. Method and Assessment of Docking Accuracy. J. Med. Chem. 2004, 47, 1739-1749. [CrossRef] [PubMed]

56. Kryger, G.; Silman, I.; Sussman, J.L. Structure of acetylcholinesterase complexed with E2020 (Aricept ${ }^{\circledR}$ ): Implications for the design of new anti-Alzheimer drugs. Structure 1999, 7, 297-307. [CrossRef]

57. Gutiérrez, M.; Theoduloz, C.; Rodríguez, J.; Lolas, M.; Schmeda-Hirschmann, G. Bioactive Metabolites from the Fungus Nectria galligena, the Main Apple Canker Agent in Chile. J. Agric. Food Chem. 2005, 53, 7701-7708. [CrossRef] [PubMed]

58. Polo, E.; Ferrer-Pertuz, K.; Trilleras, J.; Quiroga, J.; Gutiérrez, M. Microwave-assisted one-pot synthesis in water of carbonylpyrazolo[3,4-b]pyridine derivatives catalyzed by $\mathrm{InCl} 3$ and sonochemical assisted condensation with aldehydes to obtain new chalcone derivatives containing the pyrazolopyridinic moiety. RSC Adv. 2017, 7, 50044-50055. [CrossRef]

59. Gupta, A.K.; Vaishanv, N.K.; Kant, R.; Mohanan, K. Rapid and selective synthesis of spiropyrazolines and pyrazolylphthalides employing Seyferth-Gilbert reagent. Org. Biomol. Chem. 2017, 15, 6411-6415. [CrossRef]

60. Sigalov, M.; Shainyan, B.; Chipanina, N.; Ushakov, I.; Shulunova, A. Intra- and intermolecular N-H - . O hydrogen bonds in pyrrolyl derivatives of indane-1,3-dione-Experimental and theoretical study: HYDROGEN BONDS IN PYRROLYL DERIVATIVES OF 1,3-INDANDIONE. J. Phys. Org. Chem. 2009, 22, 1178-1187. [CrossRef]

61. Ramachary, D.B.; Anebouselvy, K.; Chowdari, N.S.; Barbas, C.F. Direct Organocatalytic Asymmetric Heterodomino Reactions: The Knoevenagel/Diels-Alder/Epimerization Sequence for the Highly Diastereoselective Synthesis of Symmetrical and Nonsymmetrical Synthons of Benzoannelated Centropolyquinanes. J. Org. Chem. 2004, 69, 5838-5849. [CrossRef]

62. El-Gaby, M.S.A. Syntheses of Hitherto Unknown Thiazole, Ylidene and Pyridinethione Derivatives Having a Piperidin-1-yl Moiety and Their Use as Antimicrobial Agents. J. Chin. Chem. Soc. 2004, 51, 125-134. [CrossRef]

63. Qi, J.; Zheng, J.; Cui, S. Facile synthesis of carbo- and heterocycles via Fe(iii)-catalyzed alkene hydrofunctionalization. Org. Chem. Front. 2018, 5, 222-225. [CrossRef]

64. Zhao, B.; Liang, H.-W.; Yang, J.; Yang, Z.; Wei, Y. Copper-Catalyzed Intermolecular Cyclization between Oximes and Alkenes: A Facile Access to Spiropyrrolines. ACS Catal. 2017, 7, 5612-5617. [CrossRef]

65. Becke, A.D. Density-functional thermochemistry. V. Systematic optimization of exchange-correlation functionals. J. Chem. Phys. 1997, 107, 8554-8560. [CrossRef]

66. Frisch, M.; Trucks, G.; Schlegel, H.; Scuseria, G.; Robb, M.; Cheeseman, J.; Montgomery, J.; Vreven, T.; Kudin, K.; Burant, J.; et al. Gaussian 03, Revision C.02; Gaussian. Inc.: Wallingford, CT, USA, 2004. 
67. Sánchez-Márquez, J.; Zorrilla, D.; Sánchez-Coronilla, A.; de los Santos, D.M.; Navas, J.; Fernández-Lorenzo, C.; Alcántara, R.; Martín-Calleja, J. Introducing “UCA-FUKUI" software: Reactivity-index calculations. J. Mol. Model. 2014, 20, 2492. [CrossRef] [PubMed]

68. Dennington, R.; Keith, T.; Millam, J.; Eppinnett, K.; Hovell, W.L.; Gilliland, R. GaussView, Version 3.09; Semichem, Inc.: Shawnee Mission, KS, USA, 2003. 